\title{
Physical and Chemical Characteristics of Terrace Reservoir, Conejos County, Colorado, May 1994 Through May 1995
}

by Robert W. Stogner, Sr., Patrick Edelmann, and Katherine Walton-Day

\section{U.S. GEOLOGICAL SURVEY}

Water-Resources Investigations Report 96-4150

Prepared in cooperation with the

U.S. ENVIRONMENTAL PROTECTION AGENCY

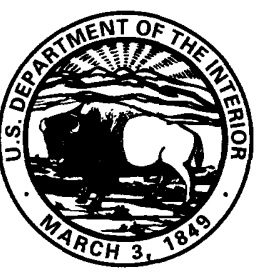




\title{
U.S. DEPARTMENT OF THE INTERIOR \\ BRUCE BABBITT, Secretary
}

\author{
U.S. GEOLOGICAL SURVEY \\ Gordon P. Eaton, Director
}

The use of firm, trade, and brand names in this report is for identification purposes only and does not constitute endorsement by the U.S. Geological Survey.

For additional information write to:

District Chief

U.S. Geological Survey

Box 25046, Mail Stop 415

Denver Federal Center

Denver, CO 80225-0046
Copies of this report can be purchased from:

U.S. Geological Survey

Branch of Information Services

Box 25286

Denver, CO 80225-0286 


\section{CONTENTS}

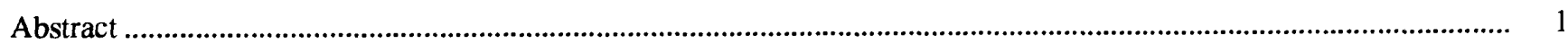

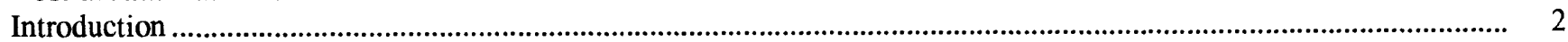

Purpose and Scope ....................................................................................................................................... 2

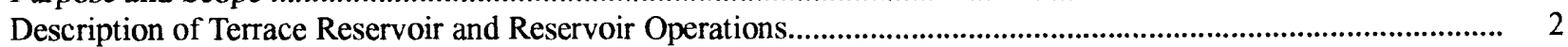

Water Quality of the Upper Alamosa River Basin ................................................................................................... 4

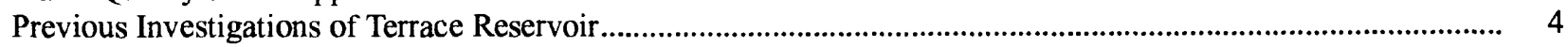

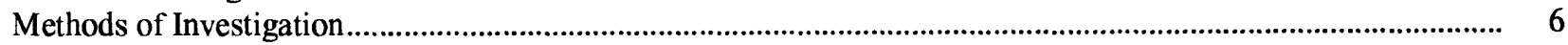

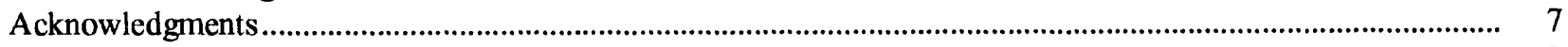

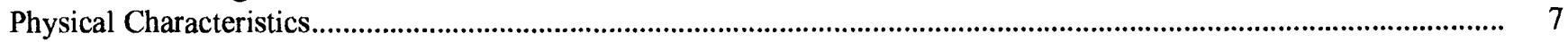

Thermal Stratification and Mixing Patterns ...................................................................................................... 8

Specific-Conductance Stratification and Mixing Patterns....................................................................................... 8

Flow-Through Patterns and Residence Times.................................................................................................... 9

Concentrations and Transport of Suspended Solids.............................................................................. 16

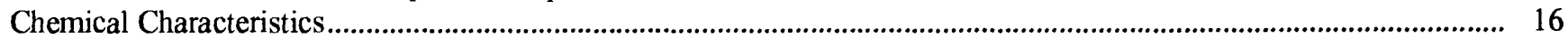

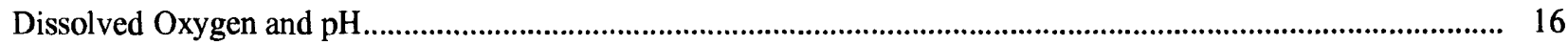

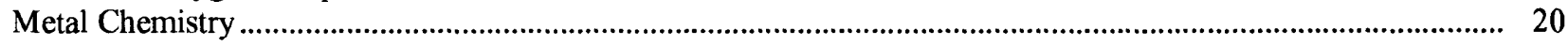

Factors Affecting Metal Distribution in Terrace Reservoir ................................................................ 21

Metal Chemistry During a Period of Thermal Stratification .................................................................... 23

Metal Chemistry During a Well-Mixed, Low-pH Period.......................................................................... 28

Metal Chemistry During a Period of Ice Cover and Elevated Hypolimnetic pH.......................................... 28

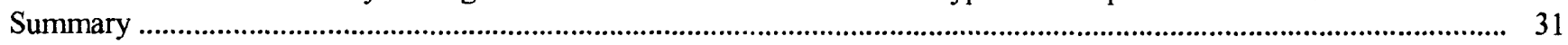

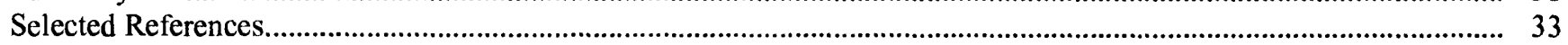

\section{FIGURES}

1. Map showing location of Terrace Reservoir, location of sampling sites upstream and downstream from

Terrace Reservoir, and sampling sites in Terrace Reservoir

2-13. Graphs showing:

2. Terrace Reservoir inflow (site AR34.5) and outflow (site AR31.0), April 1994 through March 1995 and approximate reservoir volume, May 1994 through September 1994

3. Water-temperature profiles at selected sites at Terrace Reservoir, $(A)$ May through August 1994 and $(B)$ September 1994 through May 1995

4. Specific-conductance profiles at selected sites at Terrace Reservoir, $(A)$ May through August 1994 and $(B)$ September 1994 through May 1995

5. Estimated residence times for Terrace Reservoir May 15 through September 25,1994........................... 12

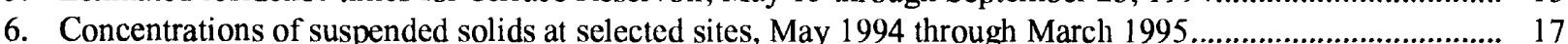

7. Profiles of $\mathrm{pH}$ at selected sites at Terrace Reservoir, $(A)$ May through August 1994 and (B) September 1994 through May 1995

8. Factors that potentially affect the distribution of metal concentrations in the water column of Terrace Reservoir ................................................................................................................................ 22

9. Dissolved-metal concentrations in Terrace Reservoir, June 1994 ................................................................. 24

10. Dissolved-metal concentrations in Terrace Reservoir, July 1994 ............................................................. 25

11. Dissolved-metal concentrations in Terrace Reservoir, August 1994 .................................................... 26

12. Dissolved-metal concentrations in Terrace Reservoir, September 1994 .................................................... 29

13. Dissolved-metal concentrations in Terrace Reservoir, March 1995 ............................................................ 30

\section{TABLES}

1. Dates and locations of profiling and water-quality sampling in Terrace Reservoir, May 1994 through July 1995

2. Number of hours and percentage of time overflow, interflow, and underflow occurred on selected days in Terrace Reservoir based on comparison of water-temperature and specific-conductance data collected from sites AR34.5 and T5 


\begin{tabular}{rll}
\hline Multiply & By & To obtaln \\
acre & 4,047 & square meter \\
acre-foot (acre-f) & 1,233 & cubic meter \\
acre-foot per day (acre-ft/d) & 1.233 & cubic meter per day \\
cubic foot per second (ft $/ \mathrm{s})$ & 0.02832 & cubic meter per second \\
foot $(\mathrm{ft})$ & 0.3048 & meter \\
foot per day (ft/d) & 0.3048 & meter per day \\
mile $(\mathrm{mi})$ & 1.609 & kilometer \\
square mile $\left(\mathrm{mi}^{2}\right)$ & 2.59 & square kilometer \\
& & \\
\hline
\end{tabular}

Degree Celsius $\left({ }^{\circ} \mathrm{C}\right)$ may be converted to degree Fahrenheit $\left({ }^{\circ} \mathrm{F}\right)$ by using the following equation:

$$
{ }^{\circ} \mathrm{F}=9 / 5\left({ }^{\circ} \mathrm{C}\right)+32
$$

The following terms and abbreviations also are used in this report:

liter (L)

milligram per liter $(\mathrm{mg} / \mathrm{L})$

microgram per liter $(\mu \mathrm{g} / \mathrm{L})$

micrometer $(\mu \mathrm{m})$

microsiemens per centimeter at 25 degrees Celsius $(\mu \mathrm{S} / \mathrm{cm})$ 


\title{
Physical and Chemical Characteristics of Terrace Reservoir, Conejos County, Colorado, May 1994 Through May 1995
}

\author{
By Robert W. Stogner, Sr., Patrick Edelmann, and Katherine Walton-Day
}

\section{Abstract}

Terrace Reservoir receives drainage of low-pH, metal-enriched water from mineralized areas, including the Summitville Mine, within the Alamosa River Basin. Drainage from the Summitville Mine has contributed a substantial part of the metal load to Terrace Reservoir. From May 1994 through May 1995, a study was done by the U.S. Geological Survey, in cooperation with the U.S. Environmental Protection Agency, to evaluate the physical and chemical characteristics of Terrace Reservoir.

Terrace Reservoir was thermally stratified from about mid-May through August 1994. Thermal stratification was absent from September 1994 through March 1995. During periods of stratification, underflow of the Alamosa River was predominant, and residence times of the underflow were shortened by 40 to 75 percent of the theoretical residence times for a well-mixed reservoir. Transport and deposition of suspended solids in Terrace Reservoir varied spatially and temporally. Most of the suspended solids were deposited in Terrace Reservoir. The concentration of dissolved oxygen in the reservoir varied little spatially or temporally and generally was within a few tenths of the dissolved-oxygen concentration of the inflow. The $\mathrm{pH}$ of water in the reservoir generally ranged from about 4.0 to about 7.0, depending on date, depth, and location. The largest $\mathrm{pH}$ values were measured during May. A marked decrease of about $1.5 \mathrm{pH}$ units occurred at site $\mathrm{T} 5$ in the reservoir about mid-June. The $\mathrm{pH}$ of the reservoir remained at or below 5.5 from mid-June through November.

Dissolved-metal concentrations varied spatially and temporally in response to several factors, which included inflow characteristics, reservoir stratification and mixing, inflow-routing and flow-through patterns, residence times, sedimentation, dissolved oxygen, and $\mathrm{pH}$. Inflow chemistry is the dominant controlling factor of metal chemistry within Terrace Reservoir. During periods of stratification, large vertical variations in metal concentrations occurred. The highest metal concentrations in the reservoir generally were measured in the hypolimnion between June and August. During June, epilimnetic water of the reservoir had $\mathrm{pH}$ values greater than 6.0 , and metal concentrations were lower than hypolimnetic concentrations. In the hypolimnion, $\mathrm{pH}$ values were less than 5.5. The difference between the chemistry of the epilimnion and the hypolimnion was due to differences in flow routing and residence times of water in those respective layers. The dissolved-metal concentrations were larger during July and August than during June.

During September, small vertical variations in metal concentrations occurred, and the dissolvedmetal concentrations were nearly equivalent to the average August metal concentrations, indicating that the metal concentrations measured during September resulted largely from reservoir mixing. During March, the largest metal concentrations occurred in the epilimnion, where $\mathrm{pH}$ was 
about 5.5; in the hypolimnion, where the $\mathrm{pH}$ was about 6.0, dissolved-metal concentrations were substantially lower and reflected inflow concentrations.

\section{INTRODUCTION}

Terrace Reservoir is a small irrigation reservoir located on the Alamosa River in the San Juan Mountain Range in Conejos County near Capulin, Colorado (fig. 1). The Alamosa River and Terrace Reservoir are primary sources of water for crops and livestock in the southwestern part of the San Luis Valley. Irrigation ponds filled with Alamosa River water are stocked with fish for private use. The Alamosa River is important to the local economy and is a substantial component of the agricultural community (Posey and others, 1995).

The drainage basin upstream from Terrace Reservoir contains extensive areas of mineralized rocks, which in some areas have been mined and that contribute a substantial metal load to Terrace Reservoir (Walton-Day and others, 1995). Gold mining has occurred in the basin for more than 100 years, and substantial mining of gold has occurred intermittently at the Summitville Mine site (fig. 1) from 1873 to 1894 , from 1926 to 1942, and from 1986 to 1992 (U.S. Environmental Protection Agency, 1993). In December 1992, the operator of the Summitville Mine declared bankruptcy, and the U.S. Environmental Protection Agency immediately took over the Summitville Mine site under the U.S. Environmental Protection Agency Superfund Emergency Response authority. As part of risk-assessment and remediation efforts, the U.S. Geological Survey began a study on Terrace Reservoir in 1994, in cooperation with the U.S. Environmental Protection Agency, to: (1) Evaluate metal transport into and out of Terrace Reservoir; (2) characterize the physical and chemical characteristics of the reservoir, including an evaluation of the spatial and temporal distribution of metals in the reservoir; (3) determine the mass of metals in the surficial sediments and the depth of metal-enriched sediments; (4) evaluate the potential for remobilization of metals from the sediments; and (5) assess the exchange of metals between the sediments and the overlying water column.

\section{Purpose and Scope}

This report describes the physical and chemical characteristics of Terrace Reservoir. Specifically, the report describes stratification and mixing patterns, flow-through patterns, residence times, the concentration and transport of suspended solids, and the spatial and temporal variations in dissolved oxygen, $\mathrm{pH}$, and metals from May 1994 through May 1995. Measurements of water temperature and specific conductance are used to describe reservoir stratification and mixing patterns, flow-through patterns, and residence times.

Measurements of dissolved oxygen and $\mathrm{pH}$ and analysis of water-quality samples for suspended solids and metals are used to describe the spatial and temporal chemical characteristics of Terrace Reservoir. A summary of the percentage of metals in the dissolved phase is presented, and relations between $\mathrm{pH}$, specific conductance, and metals of concern are discussed. The metals analyzed in this study and that have been identified as those of primary concern in the Alamosa River were aluminum, cadmium, copper, iron, manganese, and zinc (Morrison and Knudsen Corporation and ICF Keiser Engineers, 1994). Water-quality samples also were analyzed for additional minor trace elements. However, these trace-element concentrations were less than analytical reporting levels or less than water-quality standards and were not considered to be of environmental concern. Therefore, the discussion of spatial and temporal variations in metal concentrations is limited to the metals of primary concern.

\section{Description of Terrace Reservoir and Reservoir Operations}

Terrace Reservoir is a small reservoir located in the Alamosa River Basin at an elevation of about $8,550 \mathrm{ft}$ in the San Juan Mountain Range in Conejos County near Capulin, Colorado. Terrace Reservoir is a bottom-draining reservoir with the outlet located on the reservoir bottom near the dam. At maximum pool elevation $(8,568 \mathrm{ft})$, the reservoir is about $2.7 \mathrm{mi}$ long with widths ranging from about $50 \mathrm{ft}$ near the inflow to about $1,500 \mathrm{ft}$ near the dam and with depths ranging from a few feet at the inflow to about $135 \mathrm{ft}$ near the dam. Terrace Reservoir is the only mainstem reservoir on the Alamosa River and has a drainage area of $110 \mathrm{mi}^{2}$. 

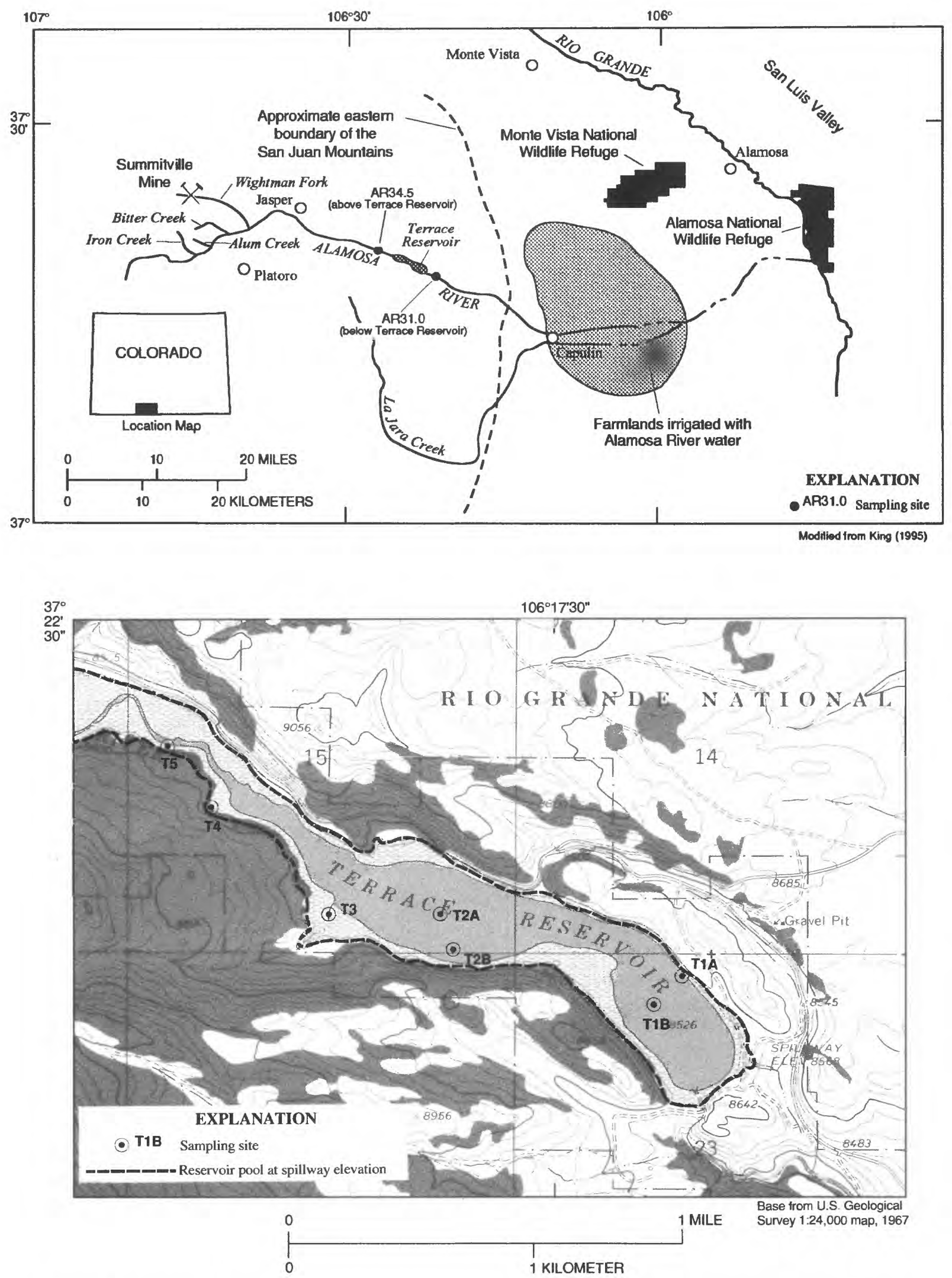

Figure 1. Location of Terrace Reservoir, location of sampling sites upstream and downstream from Terrace Reservoir, and sampling sites in Terrace Reservoir. 
When the reservoir was constructed in 1912, the initial surface area was about 300 acres and the capacity was about 17,000 acre-ft (Watts, 1996). Historically, Terrace Reservoir and the Alamosa River have had fish populations of brook trout, Rio Grande cutthroat, and rainbow trout. In the 1980's, the Colorado Division of Wildlife maintained a rainbow trout fishery in Terrace Reservoir. However, fish populations declined through the late 1980's, and by 1990 , fish were absent in Terrace Reservoir and the Alamosa River (Woodling, 1995). Currently (1996), the reservoir is operated by the Terrace Irrigation Company solely as a source of irrigation water for agricultural areas in the San Luis Valley.

Reservoir volume fluctuates seasonally in response to variations in inflow, outflow (fig. 2), and demand for irrigation water. Between November and about mid-April, reservoir outlet works are closed and storage gradually increases. During May and June 1994, the reservoir was at its annual maximum volume of about 12,000 acre-ft. However, between July and mid-August, the reservoir volume decreased 55 percent to about 5,400 acre-ft, and the reservoir pool elevation dropped by about $36 \mathrm{ft}$ due to irrigation demand. From July to mid-August, the reservoir pool receded almost $1 \mathrm{ft} / \mathrm{d}$.

\section{Water Quality of the Upper Alamosa River Basin}

Various studies have assessed water-quality conditions of the Alamosa River and source areas of low-pH and metal-enriched water in the upper Alamosa River Basin. Mueller and Mueller (1995) determined that substantial historical changes have occurred in concentrations of metals, $\mathrm{pH}$, specific conductance, and alkalinity at selected sites and during different flow regimes for the Alamosa River upstream from Terrace Reservoir. Studies conducted by Moran and Wentz (1974), Hamilton (1989), Miller and McHugh (1994), Ortiz and others (1995), Walton-Day and others (1995), and Ward and Walton-Day (1995) indicated that sources of metals and low-pH water vary spatially and temporally. However, the predominant source of low-pH, metalenriched water has been Wightman Fork (Walton-Day and others, 1995), which drains the Summitville Mine site. Concurrent with this study, Ferguson and Edelmann (1996) indicated that: (1) From April 1994 through March 1995, aluminum entered the reservoir in the suspended fraction; (2) during May and June 1994, iron and copper entered the reservoir predominantly in the suspended fraction; (3) after mid-June 1994, iron and copper predominantly entered the reservoir in the dissolved fraction; and (4) from March 1994 through April 1995, cadmium, manganese, and zinc entered the reservoir predominantly in the dissolved fraction.

\section{Previous Investigations of Terrace Reservoir}

In August 1974, as part of a State-wide lake reconnaissance, the U.S. Geological Survey, in cooperation with the Colorado Department of Natural Resources, Colorado Water Conservation Board, sampled Terrace Reservoir at two depths near the dam to assess water-quality conditions and to classify the reservoir by trophic state (Britton and Wentz, 1980). Based on two water-quality samples, one collected at a depth of $1.6 \mathrm{ft}$ and the other collected at $54.0 \mathrm{ft}$, nutrient concentrations were low, $\mathrm{pH}$ ranged between 7.0 and 8.0, specific conductance was about $200 \mu \mathrm{S} / \mathrm{cm}$, and the trophic state was classified as oligotrophic (small productivity). Water-quality analysis of the two samples collected from the reservoir indicated that dissolved-copper concentrations were 7 and $6 \mu \mathrm{g} / \mathrm{L}$, dissolved-iron concentrations were 150 and $100 \mu \mathrm{g} / \mathrm{L}$, dissolved-manganese concentrations were 400 and $420 \mu \mathrm{g} / \mathrm{L}$, dissolved-zinc concentrations were less than the analytical reporting level and $20 \mu \mathrm{g} / \mathrm{L}$, and dissolved-cadmium concentrations were less than the analytical reporting level at the surface and near the bottom of the reservoir, respectively.

In 1994, the U.S. Geological Survey (Watts, 1996), in cooperation with the U.S. Environmental Protection Agency, defined the bathymetric surface and storage capacity of the reservoir. A discussion of the volume of sediments deposited in the reservoir between 1981 and 1994 also is presented.

The exchange of dissolved trace elements between the interstitial water of Terrace Reservoir sediments and the water column, and the geochemical processes (for example, sorption, precipitation/ dissolution, and redox reactions) that affect the exchange of dissolved trace elements across the sediment-water interface are discussed by Balistrieri and others (1996). 


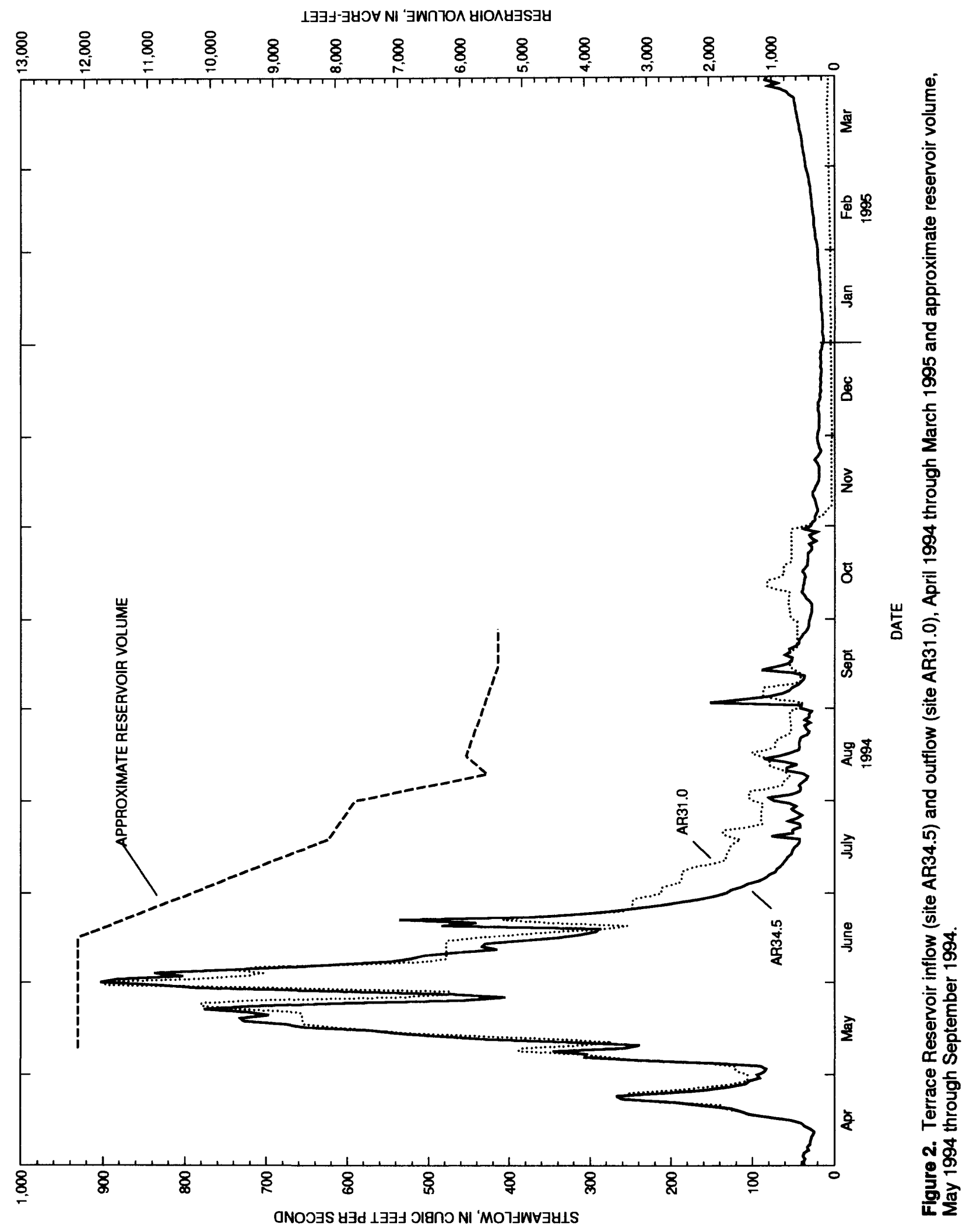


Methods of Investigation

From May 1994 to May 1995, the physical and chemical characteristics of Terrace Reservoir were evaluated using data collected at seven reservoir sites (fig. 1). The reservoir sites were selected to provide information on the spatial and temporal variations of water temperature, specific conductance, dissolved oxygen, and $\mathrm{pH}$. One site was located in the upstream end of the reservoir (T5); two sites were located about mid-reservoir (T2A, T2B); two sites were located near the dam (T1A, T1B); and two sites were located in coves along the southern shoreline (T3, T4). Onsite profile measurements were made on selected dates and at selected sites (table 1). Profile measurements are measurements of water temperature, specific conductance, dissolved oxygen, and $\mathrm{pH}$ made at selected depth increments from the surface to the bottom of the reservoir. All measurements were made during the photic, or daylight, period. In addition to profile measurements, water-quality samples were collected (table 1) at various depths from three sites that were located in the deepest part of the cross section. In addition to the reservoir sites, data collected from two sites located on the Alamosa River (referred to as sites AR34.5 and AR31.0 in this report) were used to provide information on the inflow chemistry, streamflow into and out of the reservoir, and diel variations of water temperature, specific conductance, and $\mathrm{pH}$ of water flowing into Terrace Reservoir. Streamflow data at these two sites were collected by the Colorado Division of Water Resources. The formal streamflowgaging station number and name for site AR34.5 is 08236500, Alamosa River above Terrace Reservoir, and for site AR31.0 is 08236000 , Alamosa River below Terrace Reservoir.

Prior to sample collection, all sampling equipment was thoroughly cleaned in the laboratory with a laboratory-grade detergent. The equipment then was rinsed with tap water, a dilute hydrochloric acid solution, and deionized water. The sampling equipment then was double bagged to minimize atmospheric contamination prior to sample collection. Immediately prior to collecting water-quality samples, the sampling equipment was thoroughly rinsed with reservoir water. All personnel involved in sampling-equipment preparation and sample collection and processing wore latex gloves to minimize sample contamination.

Table 1. Dates and locations of profiling and water-quality sampling in Terrace Reservoir, May 1994 through July 1995

[P, site profiled; C, water-quality samples collected]

\begin{tabular}{|c|c|c|c|c|c|c|c|}
\hline \multirow{2}{*}{ Date } & \multicolumn{7}{|c|}{ Location } \\
\hline & T5 & $\overline{T 4}$ & T3 & T2A & T2B & $\overline{T 1 A}$ & T1B \\
\hline $05 / 20 / 94$ & $\overline{\mathbf{P}}$ & $\mathbf{P}$ & $\mathbf{P}$ & $\bar{P}$ & & & \\
\hline $05 / 26 / 94$ & $\mathbf{P}$ & $\mathbf{P}$ & $\mathbf{P}$ & $\mathbf{P}$ & & & $\mathbf{P}$ \\
\hline $06 / 14-17 / 94$ & $\mathrm{P}, \mathrm{C}$ & $\mathbf{P}$ & $\mathbf{P}$ & $\mathbf{P}$ & $\mathrm{P}, \mathrm{C}$ & $\mathrm{P}, \mathrm{C}$ & $\mathbf{P}$ \\
\hline $06 / 27-28 / 94$ & $\mathbf{P}$ & $\mathbf{P}$ & $\mathbf{P}$ & $\mathbf{P}$ & $\mathbf{P}$ & $\mathbf{P}$ & $\mathbf{P}$ \\
\hline $07 / 11 / 94$ & $\mathbf{P}$ & $\mathbf{P}$ & $\mathbf{P}$ & $\mathbf{P}$ & $\mathbf{P}$ & $\mathbf{P}$ & $\mathbf{P}$ \\
\hline $07 / 18-20 / 94$ & P, C & $\mathbf{P}$ & $\mathbf{P}$ & $\mathbf{P}$ & P, C & P, C & $\mathbf{P}$ \\
\hline $08 / 01 / 94$ & $\mathbf{P}$ & $\mathbf{P}$ & $\mathbf{P}$ & $\mathbf{P}$ & $\mathbf{P}$ & $\mathbf{P}$ & $\mathbf{P}$ \\
\hline $08 / 15-17 / 94$ & $\mathrm{P}, \mathrm{C}$ & $\mathbf{P}$ & $\mathbf{P}$ & $\mathbf{P}$ & P, C & $\mathrm{P}, \mathrm{C}$ & $\mathbf{P}$ \\
\hline $09 / 26-28 / 94$ & P, C & $\mathbf{P}$ & $\mathbf{P}$ & $\mathbf{P}$ & P, C & $P, C$ & $\mathbf{P}$ \\
\hline $10 / 25 / 94$ & & & $\mathbf{P}$ & $\mathbf{P}$ & $\mathbf{P}$ & $\mathbf{P}$ & $\mathbf{P}$ \\
\hline $11 / 22 / 94$ & & & & $\mathbf{P}$ & $\mathbf{P}$ & $\mathbf{P}$ & $\mathbf{P}$ \\
\hline $01 / 24 / 95$ & $\mathbf{P}$ & & & & $\mathbf{P}$ & $\mathbf{P}$ & \\
\hline $02 / 22 / 95$ & $\mathbf{P}$ & & & & $\mathbf{P}$ & $\mathbf{P}$ & \\
\hline $03 / 13-14 / 95$ & P, C & & & & P, C & P, C & \\
\hline $05 / 10 / 95$ & P, C & & & & P, C & $P, C$ & \\
\hline $06 / 05-07 / 95$ & $\mathrm{P}, \mathrm{C}$ & $\mathbf{P}$ & $\mathbf{P}$ & $\mathbf{P}$ & P, C & $P, C$ & $\mathbf{P}$ \\
\hline $07 / 26 / 95$ & $\mathbf{P}$ & & & & $\mathbf{P}$ & $\mathbf{P}$ & \\
\hline
\end{tabular}


Water temperature, specific conductance, dissolved oxygen, and $\mathrm{pH}$ were measured using a multiparameter meter generally at 3-ft-depth intervals at all seven sites. The meter was calibrated at the beginning of each day of monitoring. Calibration for specific conductance and $\mathrm{pH}$ used standards that bracketed the expected range, and calibration for dissolved oxygen was in water-saturated air.

Based on results of profile measurements, water-quality samples generally were collected at three or four depths: one in the epilimnion, one as close as possible to the reservoir bottom without disturbing the bottom sediments, and one or two at intermediate depths to define the vertical variation in chemistry. The intermediate depths were selected based on changes in temperature, specific conductance, and $\mathrm{pH}$ with depth. Water-quality samples were collected at each depth using a 4-L, nonmetallic, 2-ftlong vertical water-sampling bottle. After the samples were collected, aliquots were collected from each sample for chemical analysis. The first aliquot collected was raw water for determination of suspended-solids concentration. The second aliquot collected, also raw water, was for determination of total-recoverable-metal analyses; the aliquot for totalrecoverable-metal analyses was acidified to a $\mathrm{pH}$ less than 2.0 using nitric acid. A third aliquot was collected for dissolved-metal analyses and filtered through a $0.45-\mu \mathrm{m}$ filter into a clean sample bottle and acidified to a $\mathrm{pH}$ less than 2.0 using nitric acid. The definition of dissolved metal is an operational one-only substances that pass through the $0.45-\mu \mathrm{m}$ filter are considered to be dissolved. However, numerous investigations of trace-element chemistry have indicated that water filtered through a $0.45-\mu \mathrm{m}$ filter can contain substantial amounts of colloidal trace elements (Kimball and others, 1995; Horowitz and others, 1996). Because colloids may pass through a $0.45-\mu \mathrm{m}$ filter, trace-metal concentrations reported as dissolved might include a substantial percentage of colloidal-size particles.

After the aliquots were collected, preserved, and processed, they were sent using chain-of-custody procedures to a U.S. Environmental Protection Agency contract laboratory. At the laboratory, the aliquots were analyzed for the primary metals of concern-dissolved and total concentrations of aluminum, cadmium, copper, iron, manganese, and zinc. In addition, dissolved and total concentrations of arsenic, chromium, cobalt, cyanide, lead, mercury, nickel, selenium, silver, and vanadium were analyzed. However, concentrations of these ancillary trace elements were less than the analytical reporting level or less than water-quality standards and, therefore, were not considered to be of environmental concern and are not considered in this report. The aliquots were analyzed for concentrations of metals and trace elements by using inductively coupled plasma (ICP) or graphite-furnace atomic absorption (GFAA) methods. Reservoir profile data are available from the U.S. Geological Survey, and reservoir chemistry data are available from the U.S. Environmental Protection Agency.

\section{Acknowledgments}

The authors would like to express special thanks for the cooperation, interest, and support provided by James Hanley, U.S. Environmental Protection Agency, and Harry H. Posey and James A. Pendleton, Colorado Department of Natural Resources, Division of Minerals and Geology. Thanks are extended to the following persons without whom the successful completion of this project would not have been possible: Craig Cotton, Colorado Division of Water Resources, Alamosa, Colorado, for providing Terrace Reservoir inflow and outflow information; Royce Reinhart, Terrace Irrigation Company, for giving us permission and access to work on the reservoir and for providing reservoir stage data; and Roderick F. Ortiz, Charles M. Moore, Nicole Nelson, Melinda Wright, and William B. Weiss, U.S. Geological Survey, for their assistance in data collection and processing.

\section{PHYSICAL CHARACTERISTICS}

The physical characteristics of the reservoir discussed in this section are thermal and specificconductance stratification and mixing patterns, flowthrough patterns and residence times, and distribution and transport of suspended solids. These characteristics affect the longitudinal and vertical distribution of $\mathrm{pH}$ and metals within the reservoir. 


\section{Thermal Stratification and Mixing Patterns}

Thermal stratification in lakes and reservoirs develops or diminishes primarily in response to seasonal changes in solar radiation; the variability of water density with temperature; wind characteristics; and, to a lesser degree, thermal gains and losses from inflows and outflows (Thornton and others, 1990). For some reservoirs in Colorado, thermal stratification and mixing patterns usually are similar from year to year (Mueller and Ruddy, 1992; Lewis and Edelmann, 1994). Typically, three distinct layers or zones develop in lakes and reservoirs: the epilimnion, an upper layer of warm, less dense water; the metalimnion, a transition zone between warmer surface water and colder deep water; and the hypolimnion, a bottom layer of colder, denser water (Goldman and Horne, 1983). During stratification, the density gradient suppresses vertical mixing between the epilimnion and hypolimnion while allowing the horizontal movement of water to become more pronounced and persistent (Wunderlich, 1971).

Thermal stratification and mixing for Terrace Reservoir were evaluated using water-temperature profile measurements that generally were made at $3-\mathrm{ft}$ depth increments from the surface to the bottom of the reservoir at several sites between the reservoir inflow and the dam. Profile measurements made within the same transect (sites T1A and T1B; sites T2A and T2B) indicated that little lateral variation in temperature, specific conductance, dissolved oxygen, and $\mathrm{pH}$ occurred within the transect - an indication that the reservoir generally was well mixed laterally. Terrace Reservoir was thermally stratified by May 20, 1994 (fig. $3 A$ ). The onset of stratification occurred with the warming spring temperatures and increasing length of daylight.

Thermal-stratification characteristics varied temporally by location within the reservoir. At the upstream site (T5), the reservoir was strongly stratified during monitoring from May 26, 1994, through August 15, 1994 (fig. 3A), despite decreasing reservoir levels and consequent increasing flow velocities as the summer progressed. During sampling in August 1994, even when the reservoir had receded to a point where site $T 5$ was part of the Alamosa River and flow was readily visible, a large decrease in temperature (about $5.5^{\circ} \mathrm{C}$ ) was observed at site $\mathrm{T} 5$ between the water surface and the reservoir bottom.
The large temperature differences at site T5 affected the initial routing of river water into the reservoir. At the middle and downstream sites (T2B and T1A), the reservoir was strongly stratified from June 15, 1994, through June 27, 1994; stratification weakened through August (fig. 3A). Between May and August, the epilimnion steadily thickened in response to solar heating, and the hypolimnion steadily thinned in response to thickening of the epilimnion and because of hypolimnetic withdrawals through the reservoir outlet. Thermal stratification was absent from September 1994, following fall turnover, through March 1995, until ice-off conditions permitted surface warming and the reestablishment of thermal stratification by at least May 1995 (fig. 3B).

\section{Specific-Conductance Stratification and Mixing Patterns}

Specific conductance is a function of dissolvedsolids concentrations. Variations in specific conductance in Terrace Reservoir are affected by routing of Alamosa River water into the reservoir as well as by thermal stratification and mixing patterns within the reservoir. The specific conductance of the Alamosa River varied inversely with discharge. Specific conductance of the river water at the inflow station (AR34.5) was lowest in May and June (106 to $223 \mu \mathrm{S} / \mathrm{cm}$ ) when streamflow was relatively large ( 190 to $920 \mathrm{ft}^{3} / \mathrm{s}$ ) because of snowmelt runoff in the upper basin. Specific conductance increased (to about $400 \mu \mathrm{S} / \mathrm{cm}$ ) with decreasing streamflow ( 25 to $80 \mathrm{ft}^{3} / \mathrm{s}$ ) during late summer and fall. The determination of stratified or mixed conditions in the reservoir with respect to specific conductance is indicated by a change in specific conductance with depth; well-mixed conditions are indicated by a uniform or nearly uniform specific-conductance profile.

Specific-conductance stratification did not follow consistent patterns as did the watertemperature profiles (figs. $4 A$ and $4 B$ ). Specificconductance stratification was well defined at site T5 on May 26, 1994, with a pronounced decrease with depth; the pronounced decrease in specific conductance was at about the same depth as the pronounced decrease in temperature. In mid-June, specific conductance was variable throughout the reservoir, but was not consistently related to depth. On June 27 and 28 , specific-conductance profiles indicated variability 
with depth at sites T5 and T2B and in July and August, specific conductance in the reservoir increased with depth. In September, after fall turnover, specific conductance was uniform with depth. Specific conductance remained uniform with depth through November. However, in January, during ice cover, there was a pronounced increase in specific conductance with depth at sites T2B and T1A (fig. 4B), indicating that there was some degree of stratification in the reservoir. This stratification probably was due to small density differences that resulted from differences in concentrations of dissolved solids between the inflow and reservoir water. This stratification was not evident in water-temperature profiles during the same period (fig. 3B). In May 1995, a few weeks after ice off, the small density differences were moderated by wind mixing, and specific conductance within the reservoir became fairly uniform with depth.

\section{Flow-Through Patterns and Residence Times}

Diel (throughout a 24-hour period) and seasonal temperature variations of inflowing water and seasonal variations in the temperature of reservoir water can cause shifts in the routing of water as it enters the reservoir. Inflow that is warmer than reservoir water will enter the epilimnion as overflow because the warmer inflow is less dense than the colder reservoir water. If warmer, less dense water is encountered by inflowing water, the inflowing water will plunge to a level of equal density. The point at which inflowing water plunges to a deeper depth due to density differences is referred to as the plunge point (Thornton and others, 1990). Interflow, which is the routing of water into the middle of the water column, results when the inflow is colder and more dense than the epilimnetic water and warmer and less dense than the hypolimnetic water. Underflow results when the inflow is colder and more dense than the reservoir water and results in routing of the inflow into the hypolimnion. Water entering the hypolimnion generally will remain in the hypolimnion and not move into other zones until fall or spring turnover disrupts stratification and mixes the reservoir water.

Initial flow routing of Alamosa River water into Terrace Reservoir was determined by comparing diel water-temperature and specific-conductance data collected at site AR34.5 and water-temperature and specific-conductance profile data collected at site T5 in Terrace Reservoir for June through August 1994 (table 2). This comparison was done only for profile dates and assumed that only minor diel variations in water temperature occurred with depth in the reservoir at site T5. For profile dates between late June and late September, inflow temperatures were matched with profile temperatures to determine initial routing of inflow water. Duration of routing to the various reservoir layers then was tabulated. Inflow routing from June through August varied temporally, but generally was dominated by underflow. In late June, when the reservoir was strongly stratified (fig. $3 A$ ) and streamflow in the Alamosa River was decreasing (fig. 2), initial inflow was routed fairly evenly between the epilimnion, the metalimnion, and the hypolimnion. However, the distribution of $\mathrm{pH}$ (discussed in the "Dissolved Oxygen and $\mathrm{pH}$ " section) and metals (discussed in the "Metal Chemistry" section) indicate that a plunge point occurred during June between sites T5 and T2B, resulting in a dominance of underflow. From July 11 through August I5, when the reservoir was stratified, water entered the reservoir as underflow 46 to 83 percent of the time, water entered as interflow 0 to 42 percent of the time, and water entered as overflow 0 to 25 percent of the time (table 2). In September, following fall turnover of the reservoir, discernible flow-through pathways diminished or were short-lived as the reservoir became well mixed.

To compare with the flow-routing analysis based on water temperature, a similar analysis was done using specific conductance as an indicator of flow routing. Initial routing of inflow water was done by matching reservoir specific-conductance values with similar values of antecedent specific conductance of the Alamosa River (table 2). The matching of reservoir specific-conductance values with similar values of antecedent specific conductance of the Alamosa River provided further information on the effect of thermal stratification on the initial routing of inflow into the reservoir and mixing patterns within the reservoir during July and August. In late June, when specific conductance within the reservoir was in a transition from decreasing with depth to increasing with depth and when initial flow routing into each layer, based on temperature, was fairly uniform, specific conductance could not be used to estimate inflow routing. However, in July and August, comparison of specific-conductance data indicated that initial flow routing was dominated by underflow. 

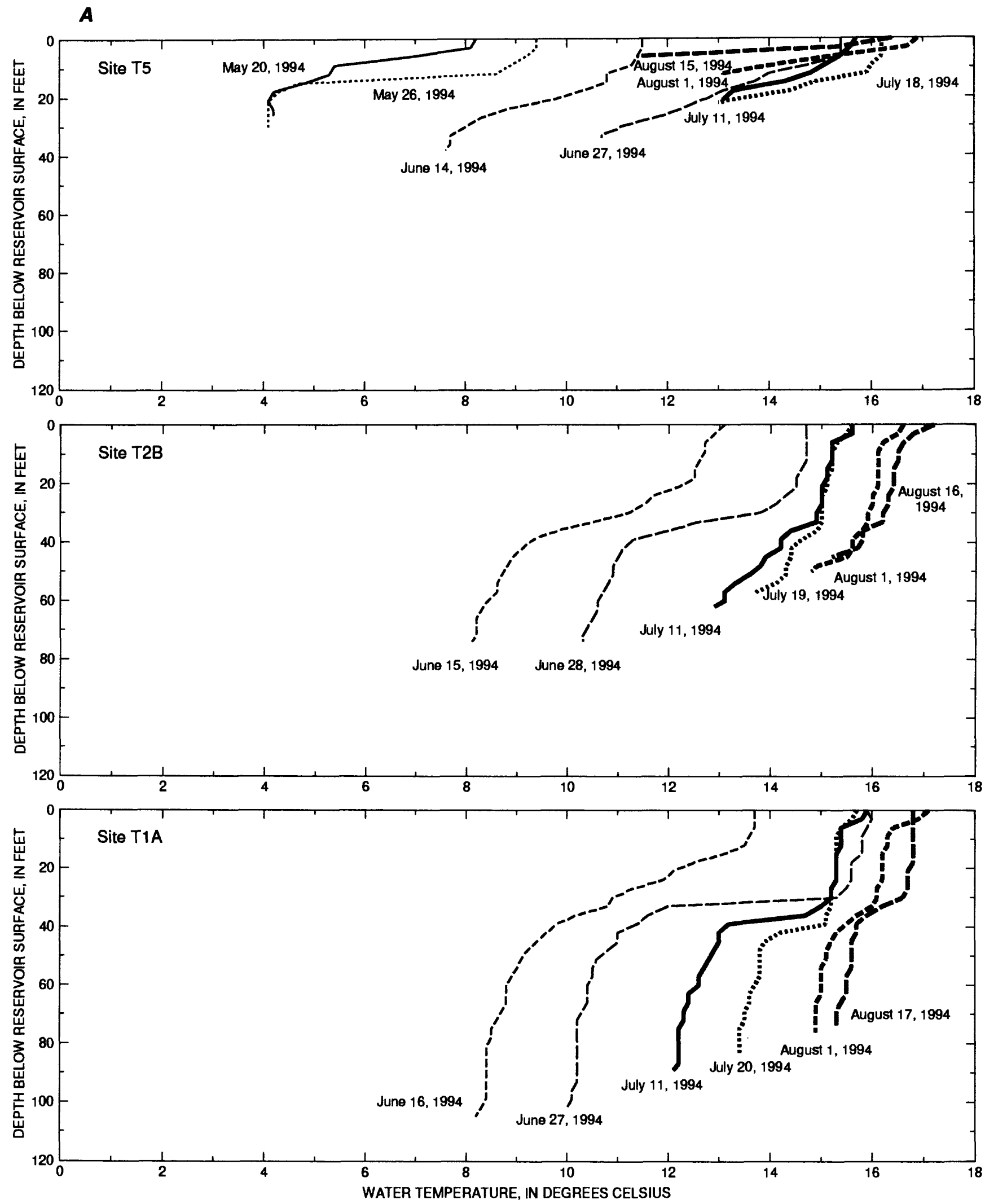

Figure 3. Water-temperature profiles at selected sites at Terrace Reservoir, (A) May through August 1994 and (B) September 1994 through May 1995. 

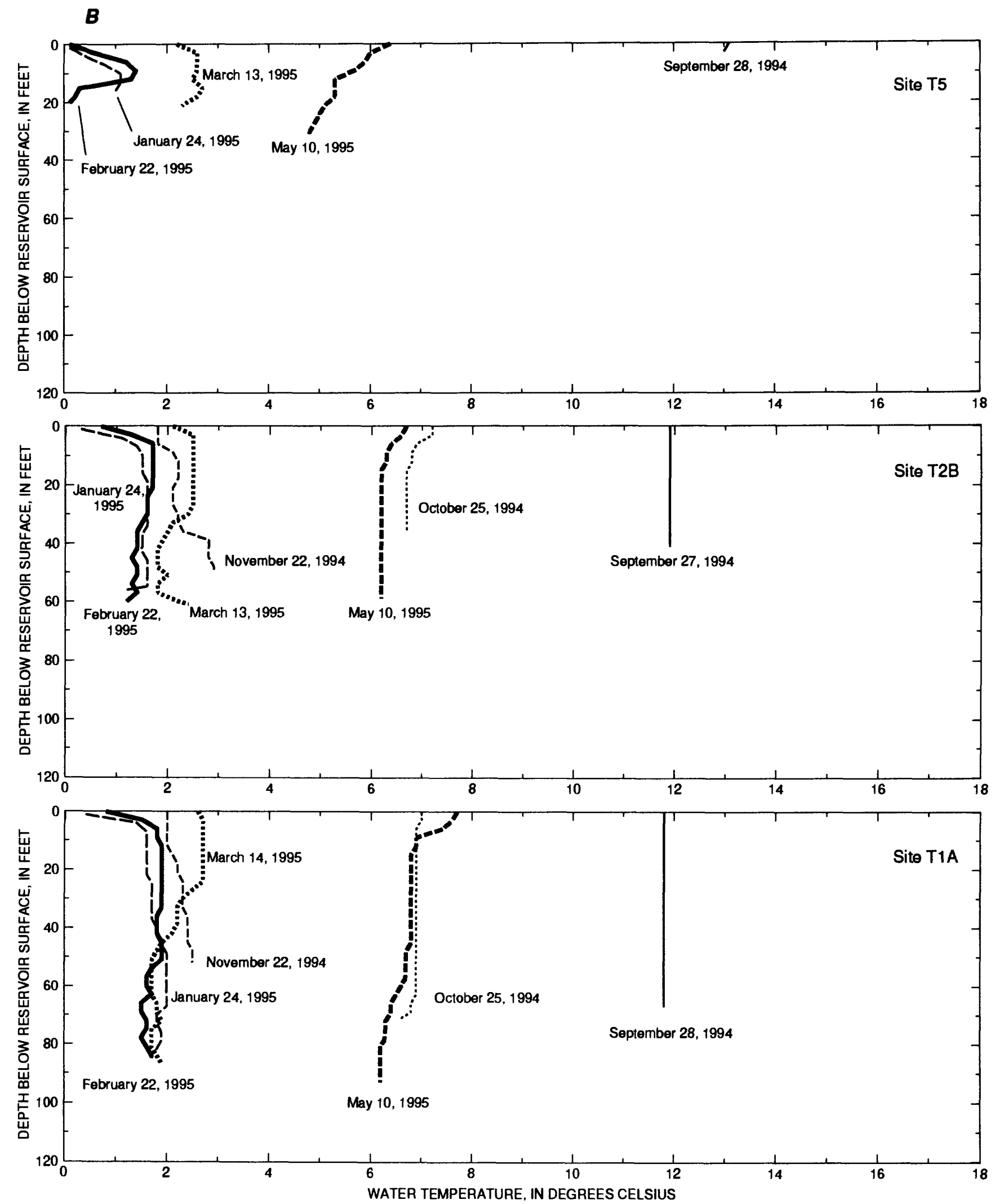

Figure 3. Water-temperature profiles at selected sites at Terrace Reservoir, (A) May through August 1994 and (B) September 1994 through May 1995-Continued. 
A
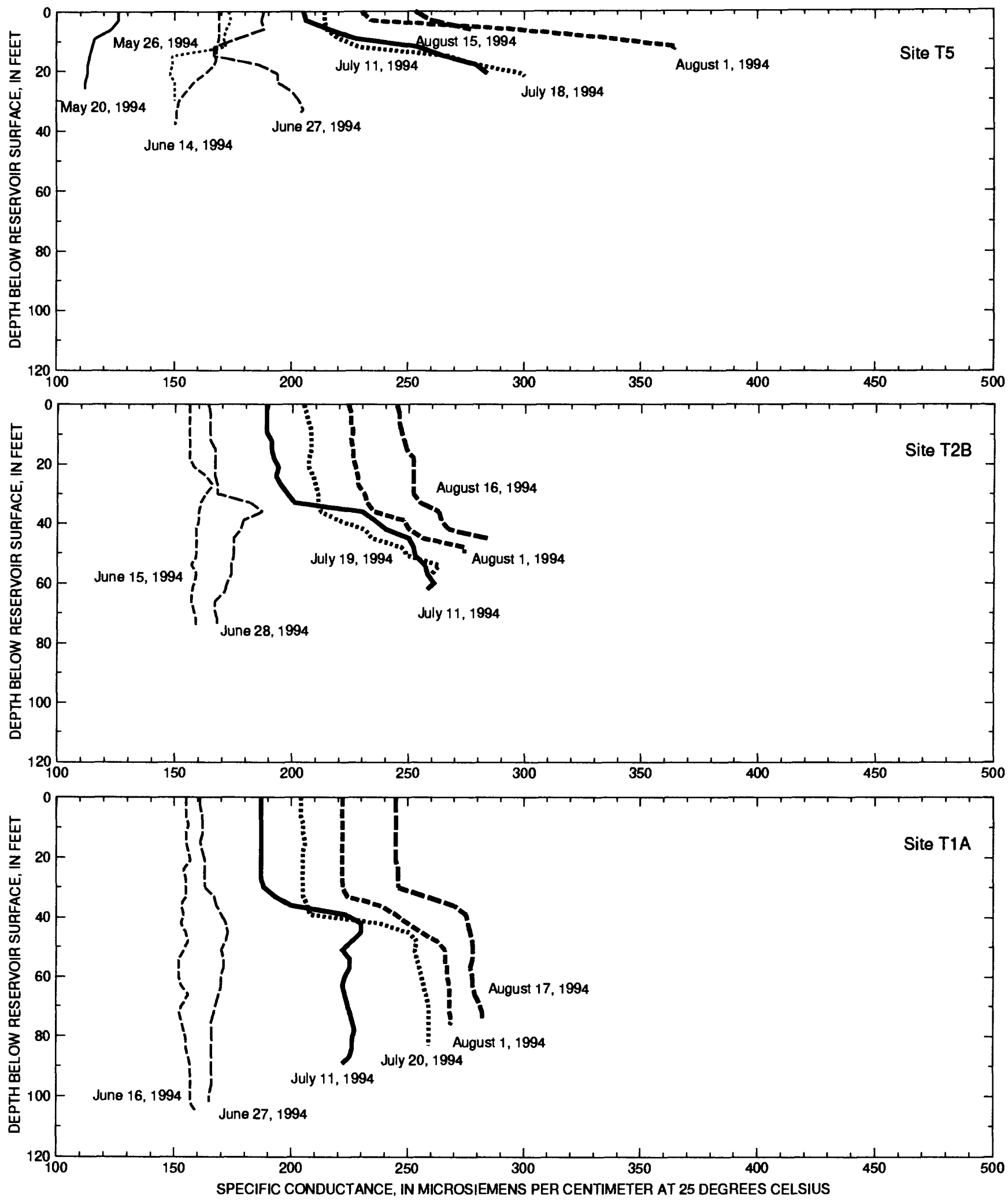

Figure 4. Specific-conductance profiles at selected sites at Terrace Reservoir, (A) May through August 1994 and (B) September 1994 through May 1995. 

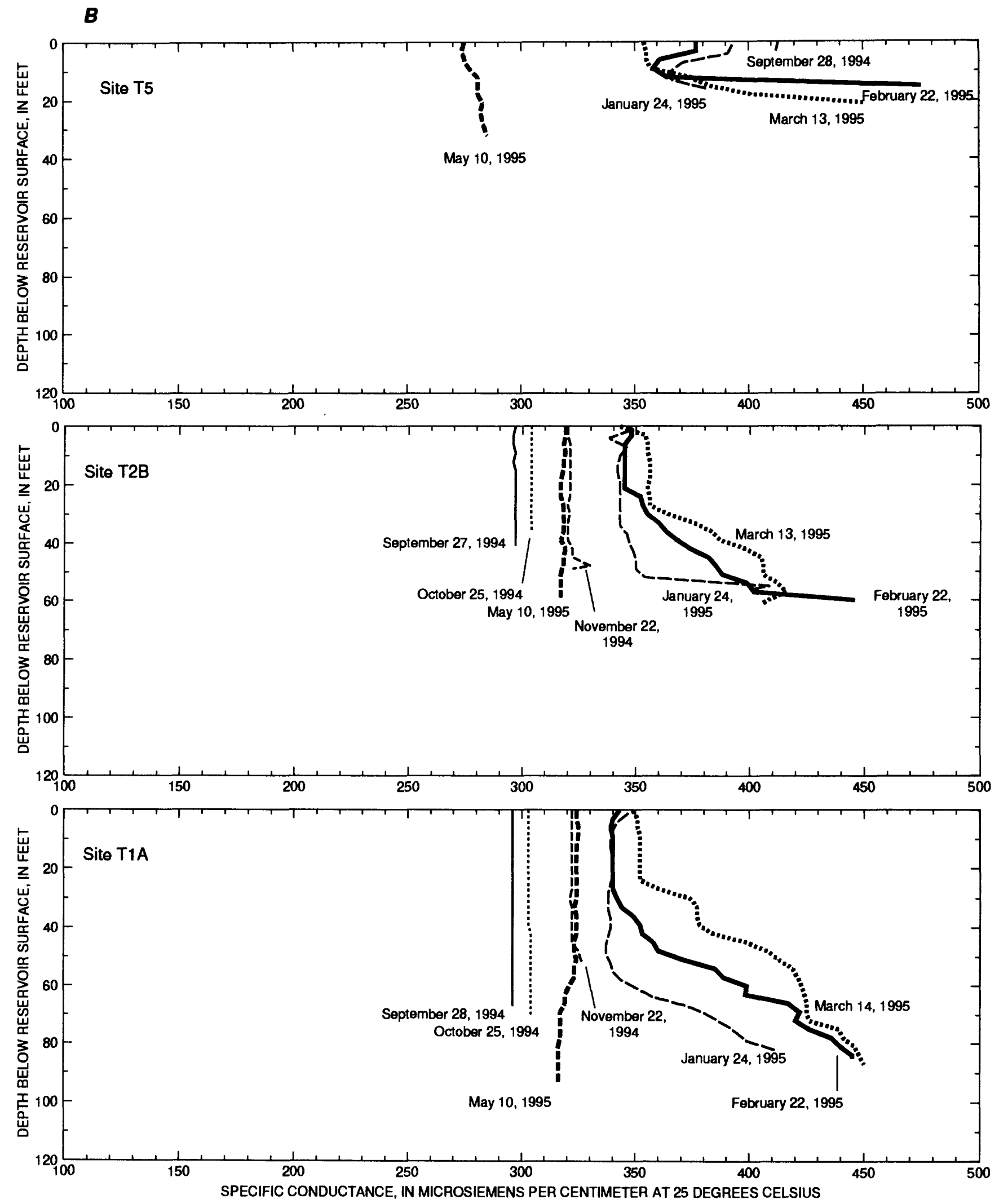

Figure 4. Specific-conductance profiles at selected sites at Terrace Reservoir, (A) May through August 1994 and (B) September 1994 through May 1995-Continued. 
Table 2. Number of hours and percentage of time overflow, interflow, and underflow occurred on selected days in Terrace Resenvoir based on comparison of water-temperature and specific-conductance data collected from sites AR34.5 and T5

\begin{tabular}{|c|c|c|c|c|c|c|}
\hline \multirow{2}{*}{$\begin{array}{l}\text { Profile } \\
\text { date }\end{array}$} & \multicolumn{2}{|c|}{ Underflow } & \multicolumn{2}{|c|}{ Interflow } & \multicolumn{2}{|c|}{ Overflow } \\
\hline & $\begin{array}{l}\text { Number of } \\
\text { hours }\end{array}$ & $\begin{array}{l}\text { Percentage of } \\
\text { total hours }\end{array}$ & $\begin{array}{l}\text { Number of } \\
\text { hours }\end{array}$ & $\begin{array}{l}\text { Percentage of } \\
\text { total hours }\end{array}$ & $\begin{array}{l}\text { Number of } \\
\text { hours }\end{array}$ & $\begin{array}{l}\text { Percentage of } \\
\text { total hours }\end{array}$ \\
\hline \multicolumn{7}{|c|}{ Water temperature } \\
\hline $06 / 27 / 94$ & 9 & 37.5 & 9 & 37.5 & 6 & 25.0 \\
\hline 07/11/94 & 19 & 79.0 & 5 & 21.0 & 0 & 0 \\
\hline 07/18/94 & 11 & 46.0 & 7 & 29.0 & 6 & 25.0 \\
\hline $08 / 01 / 94$ & 12 & 50.0 & 10 & 42.0 & 2 & 8.0 \\
\hline $08 / 15 / 94$ & 20 & 83.0 & 0 & 0 & 4 & 17.0 \\
\hline \multicolumn{7}{|c|}{ Speciffc conductance } \\
\hline 07/11/94 & 22 & 92.0 & 2 & 8.0 & 0 & 0 \\
\hline 07/18/94 & 21 & 87.5 & 3 & 12.5 & 0 & 0 \\
\hline 08/01/94 & 20 & 83.0 & 4 & 17.0 & 0 & 0 \\
\hline 08/15/94 & 24 & 100.0 & 0 & 0 & 0 & 0 \\
\hline
\end{tabular}

Theoretical residence time is defined as the time necessary for the volume of water in a reservoir to be drained by outflow. Assuming that the reservoir is well mixed, the residence time can be computed by using the following equation:

$$
\mathrm{T}=\mathrm{V} / \mathrm{Q}
$$

where

$\mathrm{T}=$ residence time, in days;

$\mathrm{V}=$ reservoir volume, in acre-feet; and

$Q$ = reservoir outflow, in acre-feet per day.

During the study, theoretical residence times for Terrace Reservoir calculated using equation 1 ranged from about 1 week during peak snowmelt runoff in late May and early June (fig. 5) to several months between fall and spring when the reservoir outlet structure was closed. When the reservoir is well mixed, from about mid-September to about mid-May, using equation 1 for estimating residence times is probably valid. However, when the reservoir is stratified, actual residence times are not accurately calculated using equation 1 . Therefore, different equations need to be used to include the effect of interflow and underflow patterns.

During periods of thermal stratification, water entering the epilimnion as overflow does not mix with underflowing water in the hypolimnion. Because the reservoir outlet structure is located on the bottom of the reservoir, the reservoir discharges hypolimnetic water, and actual residence times of water entering the epilimnion as overfiow are probably longer than the residence time calculated assuming a well-mixed condition. Between late June through mid-August 1994, it was estimated that more than two-thirds of the inflow entered Terrace Reservoir as either interflow or underflow (table 2). Interflow and underflow result in shorter flow paths and less mixing of the reservoir inflow before discharge at the dam.

Estimates of residence times for water entering Terrace Reservoir between mid-May and mid-September were made by estimating the daily volume of water that is affected by the interflow and underflow patterns that dominate during this period. Equation 1 was modified as follows:

$$
\begin{gathered}
T_{h}=V_{h} / Q \\
\text { and } \\
T_{m h}=V_{m h} / Q
\end{gathered}
$$

where

$$
\begin{aligned}
\mathrm{T}_{\mathrm{h}}= & \text { estimate of actual residence time of water } \\
& \text { in the hypolimnion, in days; } \\
\mathrm{T}_{\mathrm{mh}}= & \text { estimate of actual residence time of water } \\
& \text { in the metalimnion and hypolimnion, } \\
& \text { in days; } \\
\mathrm{V}_{\mathrm{h}}= & \text { estimate of volume of hypolimnion, } \\
& \text { in acre-feet; } \\
\mathrm{V}_{\mathrm{mh}}= & \text { estimate of combined volume of metalim- } \\
& \text { nion and hypolimnion, in acre-feet; and } \\
\mathrm{Q}= & \text { reservoir outflow, in acre-feet per day. }
\end{aligned}
$$




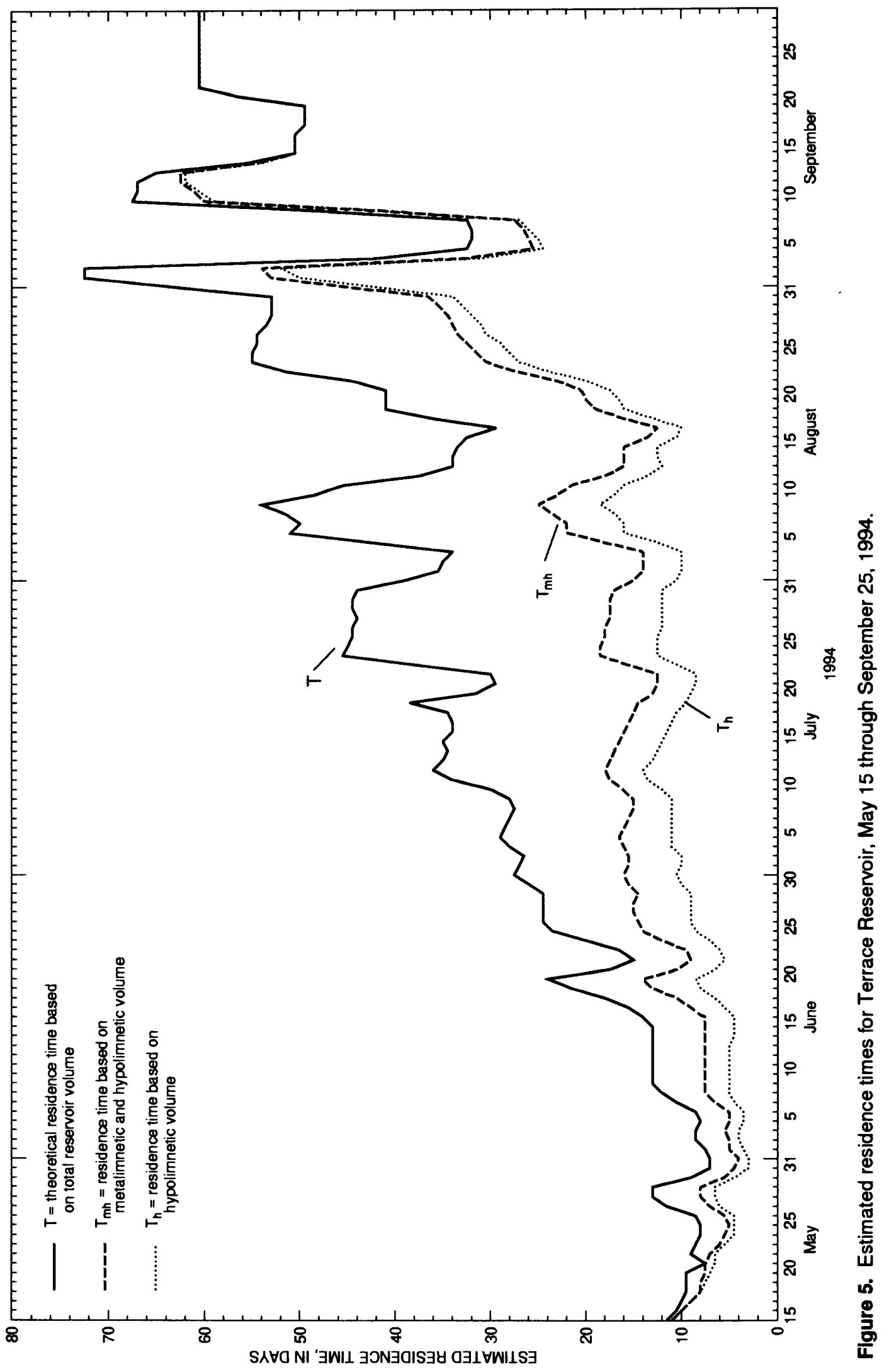

PHYSiCAL CHARACTERISTICS

15 
The upper elevation of the metalimnion and the hypolimnion was estimated for each day that water-temperature and specific-conductance profile measurements were made by interpretation of temperature and specific-conductance profiles and by making isotherm and iso-conductance plots. The elevations that corresponded to the top of the metalimnion and to the top of the hypolimnion were selected and used with area-capacity information developed by Watts (1996) to provide estimates of volumes corresponding to the metalimnion and the hypolimnion. Daily estimates of metalimnetic and hypolimnetic volumes were made by linearly interpolating between the estimated volumes for each profile date. Estimates of actual residence times of hypolimnetic volume were made by dividing the estimated volumes by the daily mean reservoir outflow. The resulting estimates are shown in figure 5 and indicate that residence times during periods of stratification generally are shortened by 40 to 75 percent of the well-mixed residence time. The shortest estimated residence times of 3 to 5 days occurred during late May to early June, a period corresponding to peak snowmelt runoff and strong thermal stratification. The short residence times during late May to early June are significant because these times reduce the amount of time for physical or chemical processing that might decrease concentrations of metals before water is released from the reservoir.

\section{Concentrations and Transport of Suspended Solids}

Concentrations of suspended solids in the Alamosa River upstream from Terrace Reservoir (site AR34.5) varied considerably (fig. 6) during the study period. In spring and summer 1994, runoff from snowmelt and summer storms contained high concentrations of suspended solids (as much as $658 \mathrm{mg} / \mathrm{L}$ ). Suspended-solids concentrations in the river were lower in fall 1994, ranging from 26 to $366 \mathrm{mg} / \mathrm{L}$, than in spring and summer 1994 and were at or less than the analytical detection level of $4 \mathrm{mg} / \mathrm{L}$ in winter 1995.

Concentrations of suspended solids in Terrace Reservoir varied spatially and temporally. Generally, most of the suspended solids transported into Terrace Reservoir were deposited upstream from site T5 as inflow velocity diminished, which was evidenced by the almost 90-percent decrease in median suspended-solids concentration from the inflow (site AR34.5) to site T5 (fig. 6). During May and early June, when streamflow was large, the suspended-solids concentrations ranged from 10 to $34 \mathrm{mg} / \mathrm{L}$ at the site downstream from the reservoir (AR31.0). Suspended-solids concentrations at site AR31.0 during other times of the year were at or less than the analytical detection level of $4 \mathrm{mg} / \mathrm{L}$. During July and August, as the summer progressed and the reservoir pool decreased, site $\mathrm{T} 5$ became more river-like. By September, the reservoir was narrow and shallow at site T5 and was merely an extension of the Alamosa River. The change in flow characteristics at site T5 allowed the transport of suspended solids farther into the reservoir; during this low-pool period, most of the suspended solids were deposited between sites T5 and $\mathrm{T} 2 \mathrm{~B}$.

\section{CHEMICAL CHARACTERISTICS}

The chemical characteristics of the reservoir discussed in this section are dissolved oxygen, $\mathrm{pH}$, and trace-metal concentrations. Dissolved oxygen and $\mathrm{pH}$ are important factors that can affect metal concentrations in Terrace Reservoir.

\section{Dissolved Oxygen and pH}

The concentration of dissolved oxygen in the reservoir varied longitudinally, vertically, and temporally due to the effect of water temperature on dissolved-oxygen concentrations. Cold, turbulent inflow, owing to the high-altitude source and steep gradient of the Alamosa River, provided a consistent supply of well-oxygenated water to the reservoir. During each measurement period, dissolved-oxygen concentrations in the reservoir generally were within $0.5 \mathrm{mg} / \mathrm{L}$ of the dissolved-oxygen concentration of the inflow. Dissolved-oxygen concentrations in the reservoir varied from 6.5 to $9.5 \mathrm{mg} / \mathrm{L}$. Due to the inverse relation between oxygen solubility and temperature, lower dissolved-oxygen concentrations occurred when water temperature was warmest, and higher dissolved-oxygen concentrations occurred when water temperature was coldest.

Biological communities used to exist in Terrace Reservoir (Britton and Wentz, 1980; Woodling, 1995). However, because of acidic, metal-enriched water, the reservoir and at least $15 \mathrm{mi}$ of the Alamosa River 


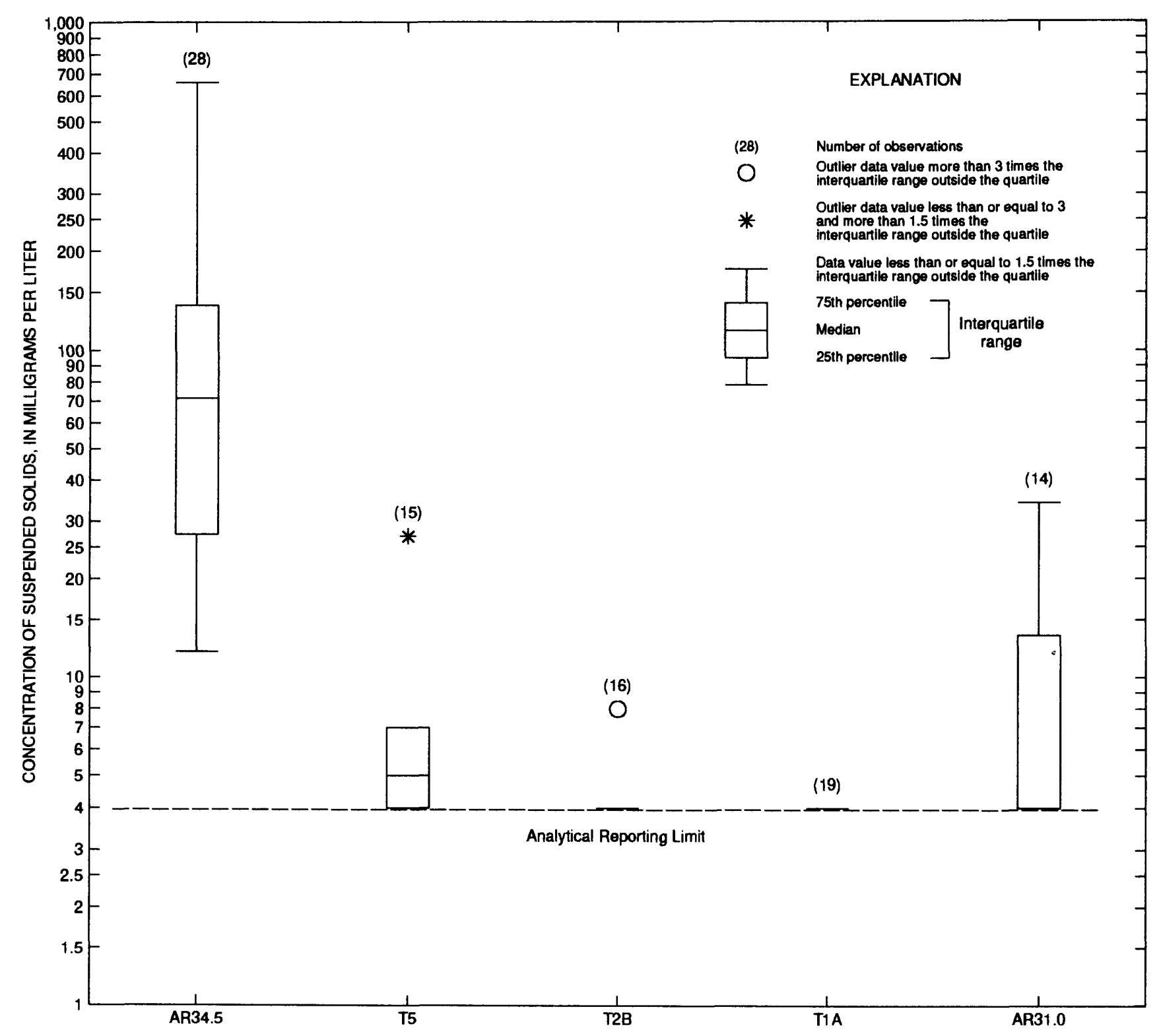

Figure 6. Concentrations of suspended solids at selected sites, May 1994 through March 1995.

upstream from Terrace Reservoir are believed to be void of fish (Woodling, 1995). Usually, photosynthesis, respiration, and decomposition have pronounced effects on the dissolved-oxygen concentrations within lakes and reservoirs. Photosynthesis near the surface of the reservoir adds oxygen to the water, whereas respiration and decomposition remove or deplete available oxygen. Because photosynthesis is limited to near the surface, respiration and decomposition create increasingly anoxic conditions with increasing depth. In general, dissolved-oxygen concentrations in Terrace Reservoir were uniform with depth or increased with depth, as temperature decreased with depth, indicating that biological processes, such as respiration and decomposition, were insufficient to cause reducing conditions in the water column.

The $\mathrm{pH}$ of the reservoir water varied with time, depth, and location (figs. $7 A$ and $7 B$ ). Changes in the $\mathrm{pH}$ of reservoir water were measured over short time periods. These changes indicate that $\mathrm{pH}$ of the reservoir is largely affected by the $\mathrm{pH}$ of the river, which can change 0.5 to 1.5 units in a day, and by routing of inflow through the reservoir. During the study, $\mathrm{pH}$ of water in the reservoir generally ranged from about 4.0 to 7.0. The largest $\mathrm{pH}$ values were measured during May 1994 and May 1995 prior to peak snowmelt runoff. 
A
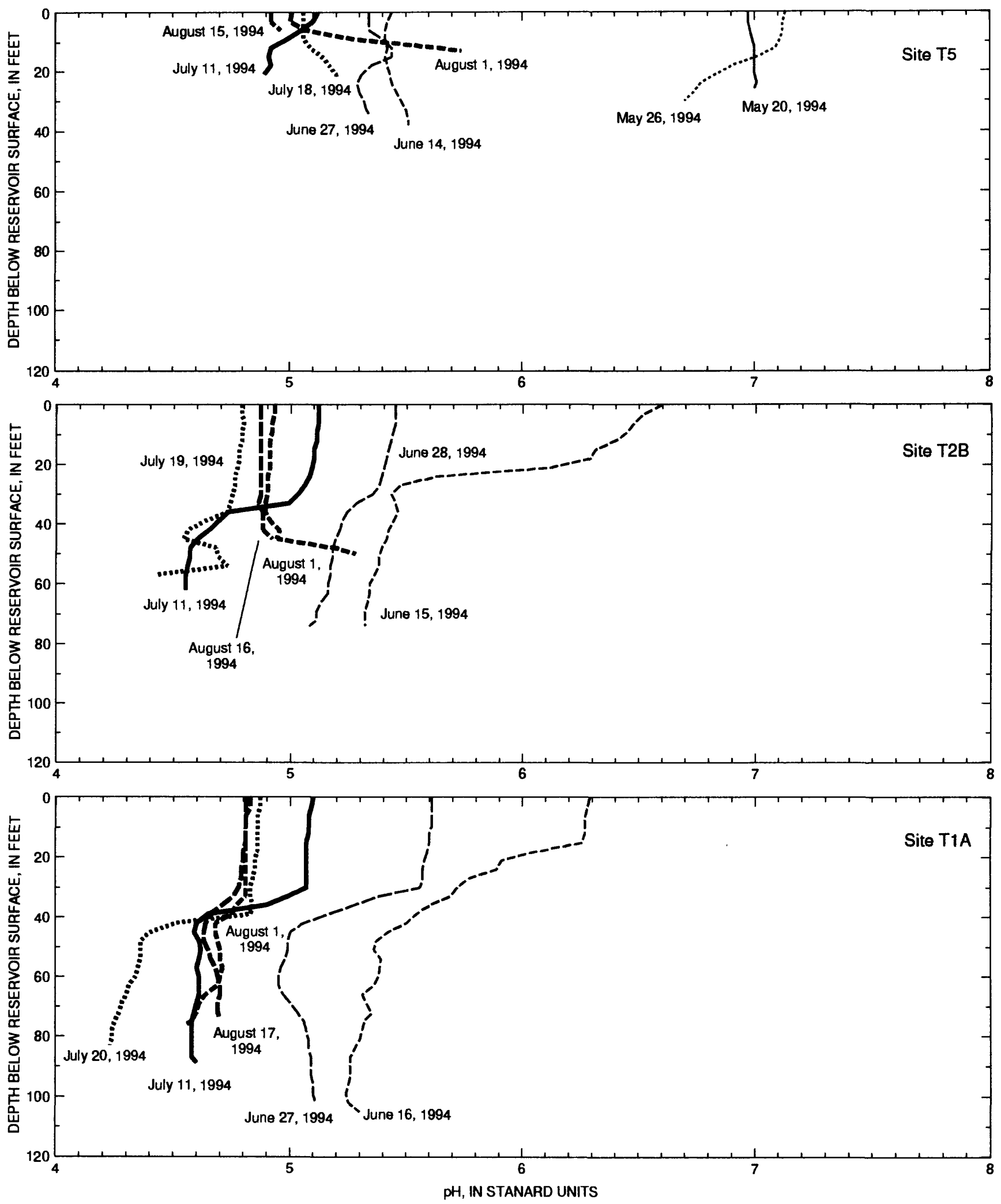

Figure 7. Profiles of pH at selected sites at Terrace Reservoir, $(A)$ May through August 1994 and (B) September 1994 through May 1995. 

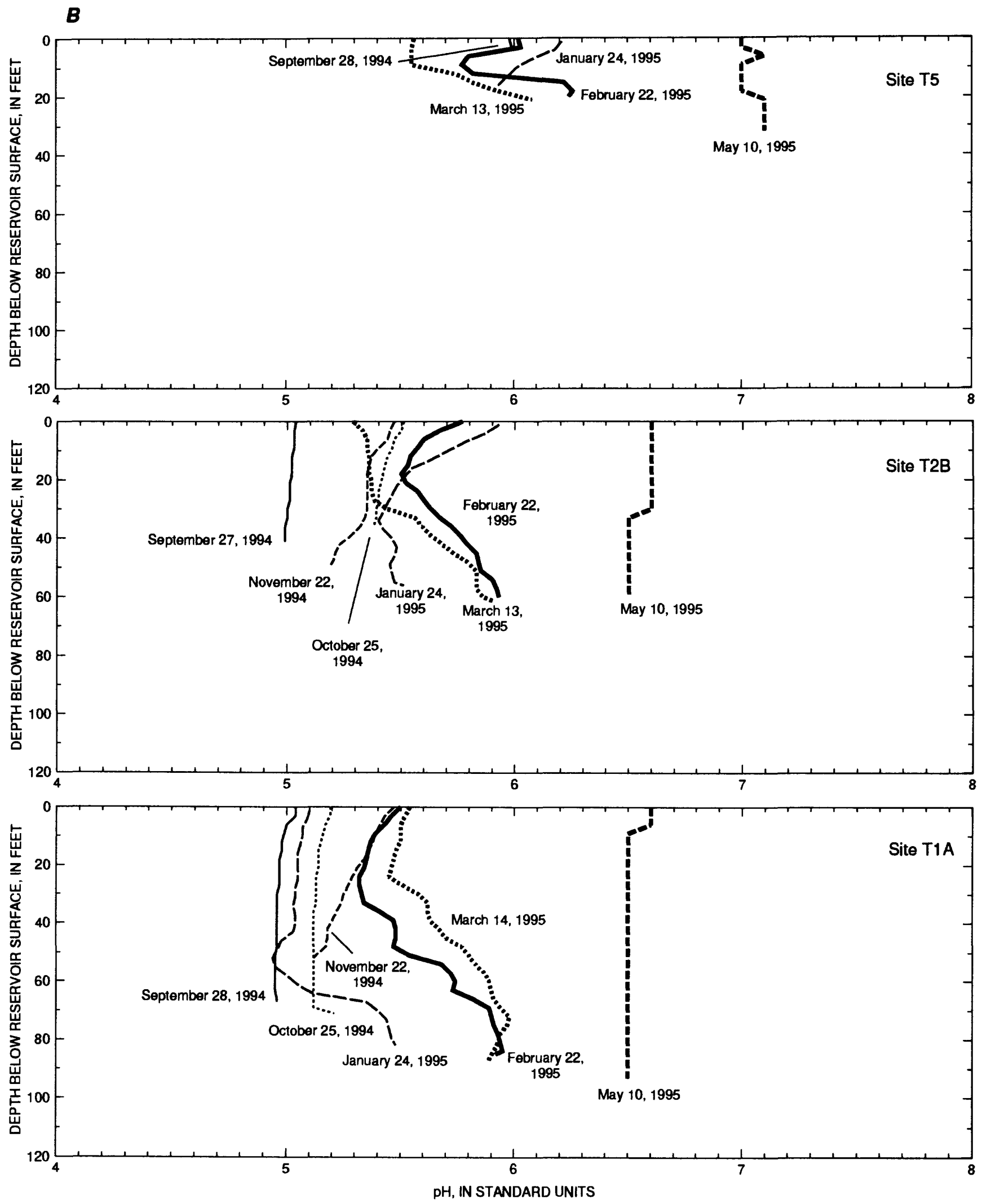

Figure 7. Profiles of pH at selected sites at Terrace Reservoir, (A) May through August 1994 and $(B)$ September 1994 through May 1995-Continued. 
Between mid-May and late June, $\mathrm{pH}$ in the reservoir markedly decreased at site T5 (fig. $7 A$ ). In mid-June, large decreases with depth were measured at sites $\mathrm{T} 2 \mathrm{~B}$ and $\mathrm{T} 1 \mathrm{~A}$. At site $\mathrm{T} 5, \mathrm{pH}$ remained fairly uniform with depth due to the initial uniform distribution of inflow during June (table 2). The decreases at sites T2B and T1A most likely were due to flowrouting changes (a plunge point) between sites $T 5$ and $T 2 B$. At the reservoir surface at sites $T 2 B$ and $\mathrm{T} 1 \mathrm{~A}, \mathrm{pH}$ values were about 1.5 standard units larger than those at site $\mathrm{T} 5$ and were indicative of the $\mathrm{pH}$ of water that entered the reservoir in mid- to late May. In the hypolimnion at sites $\mathrm{T} 2 \mathrm{~B}$ and $\mathrm{T} 1 \mathrm{~A}, \mathrm{pH}$ values were about 0.2 standard unit lower than the values at site $\mathrm{T} 5$ and were indicative of recent, lower $\mathrm{pH}$ inflow. The differences in $\mathrm{pH}$ values between epilimnetic and hypolimnetic water at sites T2B and T1A indicate that inflow routing had changed between sites $\mathrm{T} 5$ and $\mathrm{T} 2 \mathrm{~B}$. The $\mathrm{pH}$ in the reservoir decreased through the summer, reaching a minimum of about 4.9 at site T5 in August and a minimum of about 4.5 and 4.2 at sites T2B and T1A, respectively, in July (fig. $7 A$ ). The apparent decrease in minimum $\mathrm{pH}$ that was measured between site T5 and sites T2B and T1A could have resulted from: (1) Measurement of water of different residence times; (2) production of hydrogen ions due to formation of metal hydroxides in the reservoir; or (3) a combination of both. Because of the large temporal variations in $\mathrm{pH}$ that occurred in the inflow and because the minimum inflow pH was 3.6 (site AR34.5), it is probable that most of the longitudinal differences in $\mathrm{pH}$ that were observed were more related to the $\mathrm{pH}$ of the inflow than to the formation of metal hydroxides. In September, following fall turnover, $\mathrm{pH}$ values became nearly uniform with depth. During January and March 1995, when the reservoir was covered with ice, mixing by wind was eliminated, and the reservoir outlet structure was closed, large $\mathrm{pH}$ variations occurred with depth. These variations probably occurred due to variations in initial flow routing of water from the Alamosa River. During March, $\mathrm{pH}$ markedly increased with depth throughout most of the reservoir (fig. $7 B$ ) and was indicative of inflow with $\mathrm{pH}$ ranging from 6.3 to 6.8 (site AR34.5) being routed under reservoir water that had $\mathrm{pH}$ values ranging from 5.1 to 5.9. Following ice off in April 1995, mixing of reservoir water during spring turnover resulted in nearly uniform $\mathrm{pH}$ with depth in May 1995.

\section{Metal Chemistry}

Water-quality samples were collected during June, July, August, and September 1994 and March 1995 at three locations to describe spatial and temporal variations in trace-element concentrations in Terrace Reservoir. Samples were analyzed for the primary metals of concern-dissolved and total-recoverable aluminum, cadmium, copper, iron, manganese, and zinc.

Dissolved- and total-recoverable-metal concentrations in Terrace Reservoir varied spatially and temporally. Within Terrace Reservoir, cadmium, copper, manganese, and zinc predominantly were in the dissolved fraction. More than 90 percent of these metals were in the dissolved fraction in about 90 percent of the samples. The percent dissolved iron was greater than 80 percent in about 66 percent of the samples. Depending on location and sampling date, the percent dissolved aluminum varied from about 2 to more than 100 percent. Because the metals generally were in the dissolved fraction, the discussion of metal chemistry mostly is limited to the distribution of dissolved-metal concentrations.

Twenty percent of the samples for all the metals had dissolved-metal concentrations that exceeded total-recoverable-metal concentrations by more than 15 percent, most of which occurred in July. Laboratory personnel indicated that laboratory precision and accuracy of quality-assurance and quality-control samples were within 10 percent (Barbara Debou, oral commun., 1996). In addition, field quality-assurance and quality-control samples indicated that no substantial contamination of environmental samples occurred during sample collection and processing, and analyses of replicate samples generally were within 10 percent. Further review of the data did not resolve the anomalies and resulted in some uncertainty in the reported metal concentrations.

Longitudinal and vertical variations in metal concentrations in Terrace Reservoir during the study period are presented for three sampling periods. Metal analysis of samples collected from June through August 1994 were used to describe the distribution of metal concentrations that occurred during a period of thermal stratification; metal analysis of samples collected in September 1994 were used to describe the distribution of metal concentrations that occurred during a well-mixed, low-pH period; and metal analysis of samples collected during March 1995 were 
used to describe the distribution of metal concentrations that occurred when the reservoir was covered with ice, and the $\mathrm{pH}$ was elevated in the hypolimnion.

\section{Factors Affecting Metal Distribution in Terrace Reservoir}

Several factors can potentially affect the distribution of metal concentrations in the water column of Terrace Reservoir (fig. 8). These factors include the physical and chemical characteristics of the inflow and the physical, chemical, and biological characteristics of the reservoir. Changes in streamflow, water temperature, dissolved-oxygen concentrations, $\mathrm{pH}$, and concentrations of metals in the Alamosa River upstream from the reservoir (Patrick Edclmann and Sheryl Ferguson, U.S. Geological Survey, written commun., 1995) also affect the distribution of metal concentrations in the water column of Terrace Reservoir.

Physical factors and processes within Terrace Reservoir that affect distribution of metal concentrations in the water column include thermal stratification, inflow-routing and flow-through patterns, reservoir residence times, and the deposition of particulate matter. As previously discussed, thermal stratification of the reservoir resulted in limited or inhibited vertical mixing between limnetic layers and enhanced horizontal movement within the various limnetic layers. Inflow from the Alamosa River is initially routed to various depths within the reservoir because of density differences between the inflow and the reservoir water column. The initial flow routing and the flow-through patterns within the reservoir affect the reservoir residence time of inflowing water. During periods of stratification, water that was routed to the hypolimnion moved through the reservoir faster than epilimnetic water due to the location of the reservoir outlet. Water with short residence times has less time for physical and chemical processes to affect metal concentrations of incoming water before being rcleased downstream.

Deposition of particulate-metal concentrations substantially decreased the amount of particulate or suspended concentrations of metals in the water column in Terrace Reservoir. During collection of 30 reservoir-bottom sediment samples, A.J. Horowitz (U.S. Geological Survey, written commun., 1995) observed that "the bottom of the reservoir was covered by a thin, soupy, extremely fine-grained red-orange-floc.... Based on color, it was inferred that the floc contained, or was composed of, substantial quantities of iron oxide." Assuming these observations were correct, a substantial amount of ferric hydroxide settled out of the water column in Terrace Reservoir. As metals partition to the solid phase and settle from the water column, particulate-metal concentrations in the reservoir water column decrease. Ferguson and Edelmann (1996) indicated that 81 percent of the total-recoverable aluminum load, 75 percent of the total-recoverable iron load, and 36 percent of the total-recoverable copper load that cntered the reservoir between April 1994 through March 1995 settled from the water column and were deposited to the reservoir sediments.

Dissolved-oxygen concentrations and $\mathrm{pH}$ in the reservoir affect the distribution of metal concentrations in the reservoir. During the study, the welloxygenated state of the reservoir, coupled with the apparent limited microbial activity in the reservoir, probably limited the types of reactions or processes that could have occurred in the reservoir to: oxidation and precipitation of ferric hydroxides, adsorption and desorption of metals, complexation of dissolved metals with ligands, and flocculation. Furthermore, the well-oxygenated state of the river and the measured ranges in $\mathrm{pH}$ in the river indicate that most of the ferric hydroxide probably formed in the river upstream from Terrace Reservoir. During the formation of metal hydroxides, hydrogen ions are produced, and the $\mathrm{pH}$ of the water decreases. If ferric hydroxide formation was occurring within the reservoir, a noticeable decrease in $\mathrm{pH}$ below inflow values should have been measured. In gencral, the $\mathrm{pH}$ distribution in the reservoir secmed to be more related to the $\mathrm{pH}$ of the inflow than to formation of metal hydroxides in the reservoir. Therefore, during the study, the oxidation and chemical precipitation of metal hydroxides, such as ferric hydroxide, probably were not a dominant process in the reservoir.

Biological processes also can affect metal concentrations. In many reservoirs, respiration and the decomposition of organic matter result in the occurrence of reducing conditions in the water column. If sulfate reduction occurs, metal concentrations can be attenuated through the formation of relativcly insoluble metal-sulfide mineral phases. As these minerals settle and are preserved in the reservoir-bottom sediments, the deposited metals are no longer available for transport from the reservoir. 


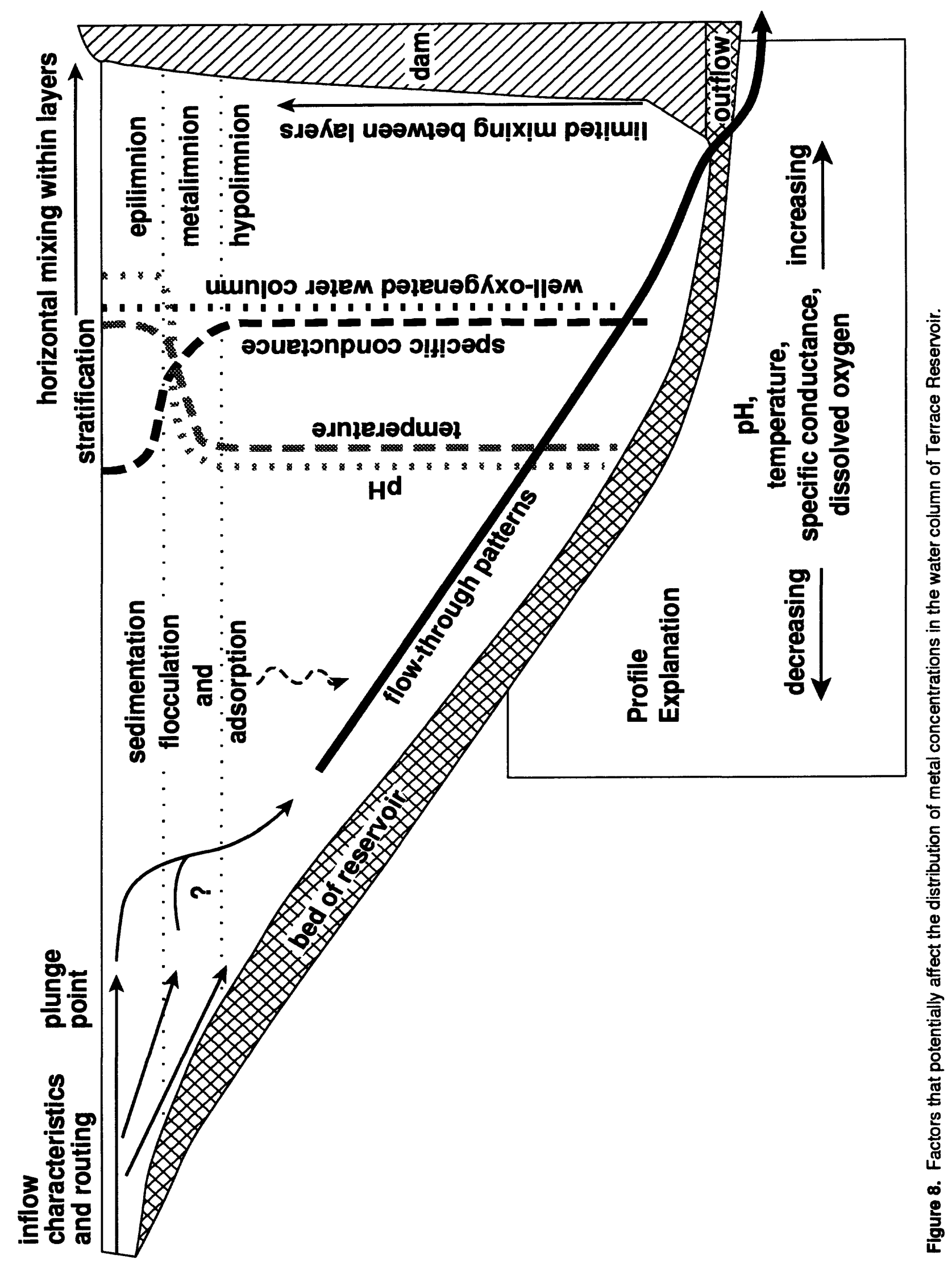


The well-oxygenated state of Terrace Reservoir indicates that reducing conditions did not occur in the water column. Therefore, sulfate reduction in the water column was unlikely, and attenuation of metals due to formation of metal sulfides was improbable.

\section{Metal Chemistry During a Period of Thermal Stratification}

Between June and August 1994, the reservoir was thermally stratified and residence times were short. During this period, large longitudinal, vertical, and temporal variations in metal concentrations occurred in the reservoir (figs. 9-11).

During late June 1994, residence time of hypolimnetic water was near its annual minimum (fig. 5), the reservoir was well oxygenated and strongly stratified (fig. $3 A$ ), and water entering the reservoir from the Alamosa River was initially distributed fairly evenly into the epilimnion, metalimnion, and hypolimnion (table 2). However, a plunge point between sites $\mathrm{T} 5$ and $\mathrm{T} 2 \mathrm{~B}$ probably occurred as indicated by the increase in the $\mathrm{pH}$ in the epilimnion from about 5.4 in the upstream part of the reservoir (site T5) to about 6.4 at mid-reservoir (site T2B) and at the dam (site T1A) in June 1994 (fig. 7A). Epilimnetic $\mathrm{pH}$ at sites T2B and T1A was indicative of Alamosa River water (site AR34.5) entering the reservoir from late May to early June. Dissolved-iron concentrations in the epilimnion decreased by nearly 100 percent from $2,400 \mu \mathrm{g} / \mathrm{L}$ at site $\mathrm{T} 5$ to $40 \mu \mathrm{g} / \mathrm{L}$ at site $\mathrm{T} 2 \mathrm{~B}$ and to less than $15 \mu \mathrm{g} / \mathrm{L}$ at site $\mathrm{T} 1 \mathrm{~A}$ in June 1994 (fig. 9). Dissolved-iron concentrations in samples collected at the inflow site (AR34.5) from May through mid-June ranged from 193 to $3,100 \mu \mathrm{g} / \mathrm{L}$ (Ferguson and Edelmann, 1996). The differences in concentrations of dissolved iron between the inflow site and site T1A indicate that, in addition to sampling of water of different residence times, the decrease in dissolved-iron concentrations that occurred in the epilimnion between sites T5 to T1A partially was due to the settling of colloidal iron hydroxides. Dissolvedaluminum concentrations decreased from $291 \mu \mathrm{g} / \mathrm{L}$ at site T5 to less than $40 \mu \mathrm{g} / \mathrm{L}$ at sites T2B and T1A in June 1994 (fig. 9). Dissolved-aluminum concentrations in samples collected from the inflow from May through mid-June ranged from 40 to $292 \mu \mathrm{g} / \mathrm{L}$ and were consistent with the hypothesis that variations in dissolved-aluminum concentrations between sites $\mathrm{T} 5$ and T1A largely were due to sampling of water of different residence times rather than to adsorption, co-precipitation with iron hydroxide, or precipitation of aluminum hydroxides. Concurrent with the longitudinal decrease in iron and aluminum concentrations, the percent particulate fraction of iron and aluminum increased, indicating that dissolved iron and aluminum either precipitated out of solution or colloidal iron and aluminum flocculated and settled from the water column. Total-iron and -aluminum concentrations of the inflow from May through early June showed considerable variation $(3,600$ to $16,800 \mu \mathrm{g} / \mathrm{L}$ for iron and 1,870 to $6,370 \mu \mathrm{g} / \mathrm{L}$ for aluminum), but generally were closer to the lower limit of the range in concentrations. Total-iron and -aluminum concentrations within Terrace Reservoir decreased downstream $(3,060 \mu \mathrm{g} / \mathrm{L}$ iron at site T5 to $644 \mu \mathrm{g} / \mathrm{L}$ iron at site T1A and $656 \mu \mathrm{g} / \mathrm{L}$ aluminum at site $\mathrm{T} 5$ to $131 \mu \mathrm{g} / \mathrm{L}$ aluminum at site $\mathrm{T} 1 \mathrm{~A}$ ) due to settling of particulate metals from the water column. Epilimnetic concentrations of dissolved copper, cadmium, and zinc also substantially decreased between sites T5 and T1A (fig. 9) due primarily to sampling of water of different residence times. Within the hypolimnion, dissolved-metal concentrations had considerably less longitudinal variation than occurred in the epilimnion (fig. 9) and were consistent with concentrations in water that recently entered the reservoir. Dissolved-iron concentrations showed the largest variations with a decrease of about 35 percent between sites T5 and T2B/T1A. The other metals had less variation; concentrations of dissolved aluminum and zinc showed almost no change (less than 5 percent), and concentrations of dissolved cadmium, copper, and manganese decreased by less than 15 percent. Corresponding to the small longitudinal variations that occurred in the hypolimnion, the dissolved-metal concentrations measured at sites T2B and T1A near the reservoir bottom were substantially greater than the concentrations measured near the reservoir surface at sites T2B and T1A (fig. 9), which is consistent with the short residence time of the hypolimnetic waters, which was estimated to be about 5 days, resulting in rapid flushing of the water in the hypolimnion and replacement with water from the Alamosa River having larger metal concentrations. The large vertical variations in metal concentrations may have been accentuated because strong thermal stratification during mid-June inhibited vertical mixing and promoted horizontal movement of water. 

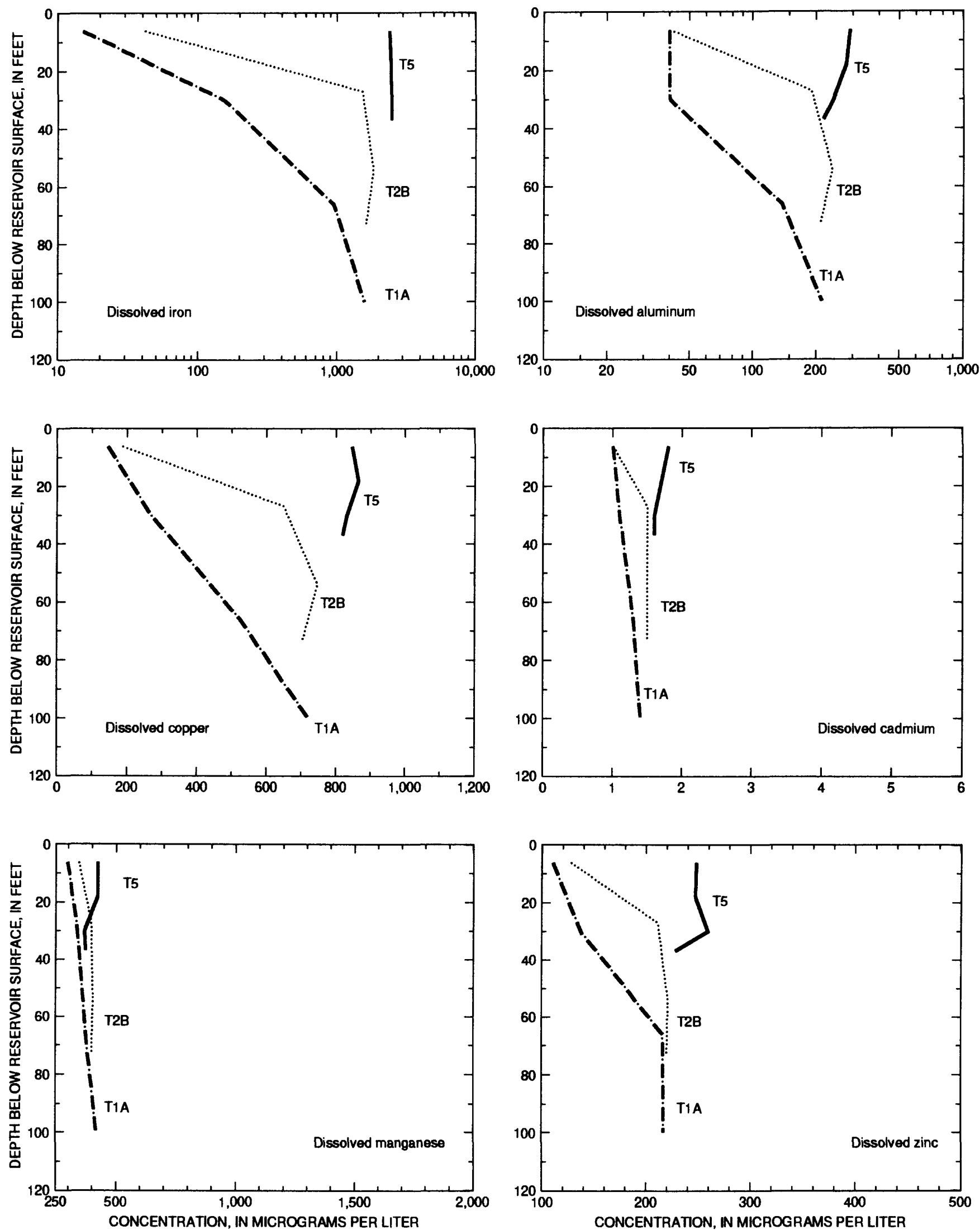

Figure 9. Dissolved-metal concentrations in Terrace Reservoir, June 1994. 

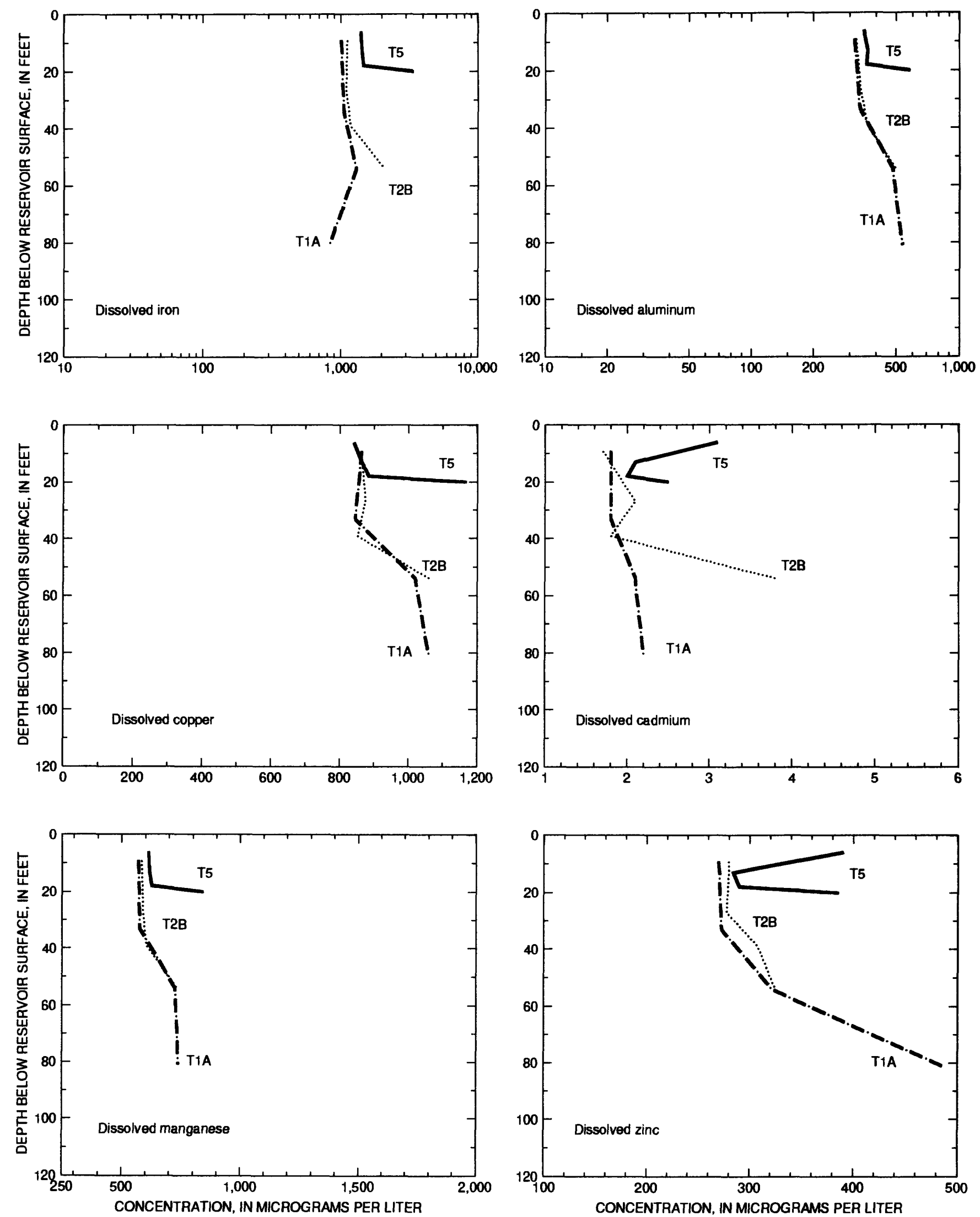

Figure 10. Dissolved-metal concentrations in Terrace Reservoir, July 1994. 

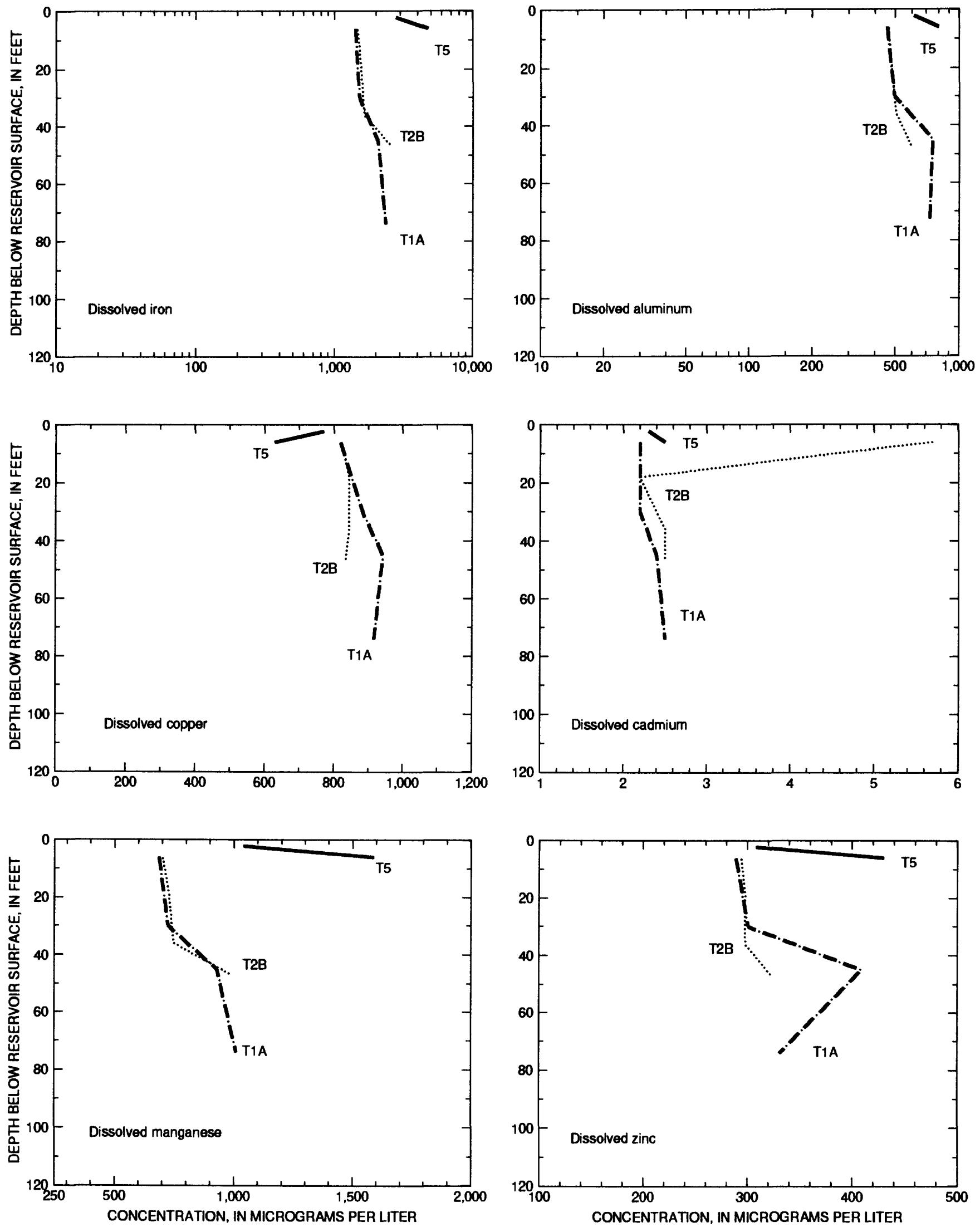

Figure 11. Dissolved-metal concentrations in Terrace Reservoir, August 1994.

26 Physical and Chemical Characteristics of Terrace Reservoir, Conejos County, Colorado, May 1994 Through May 1995

*U. S. GOVERNMENT PRINTING OFFICE 1997-0-573-230/40024 
In order to assess whether adsorption of trace elements to ferric hydroxides was an important process in metal attenuation in Terrace Reservoir during the study period, a limited modeling exercise was performed using MINTEQA2 (Allison and others, 1991) coupled with the Generalized TwoLayer Sorption Model (Dzombak and Morel, 1987). In this exercise, data from the epilimnion and hypolimnion at sites T5, T2B, and T1A in June 1994 were input into the model. This date was chosen because the $\mathrm{pH}$ values were large enough for some sorption to occur (Smith and others, 1992).

The amount of ferric hydroxide was computed by converting the concentration of suspended or particulate iron (concentration of total-recoverable iron minus concentration of dissolved iron) to an equivalent concentration of suspended ferric hydroxide. The modeling assumed that this amount of ferric hydroxide was the only sorbent material. Concentrations of total-recoverable calcium, magnesium, sodium, potassium, chloride, sulfate, aluminum, iron, copper, zinc, and manganese, and values of temperature, carbon dioxide, and $\mathrm{pH}$ were input into the model. The model simulates what proportions of the input concentrations should partition to the dissolved and sorbed (suspended or particulate) phases. These simulated concentrations then are compared to measured values for dissolved and particulate matter where the particulate concentration is the difference between total-recoverable and dissolved concentrations. This modeling technique has been used to successfully predict dissolved and particulate concentrations for various mine-drainage waters collected across the Western United States (Smith and others, 1992).

A comparison of the simulated results to the data collected from the epilimnion and hypolimnion at site T5 and from the hypolimnion at sites T2B and T1A generally were within 10 percent and indicated that $\mathrm{pH}$ and suspended sorbent material in the reservoir were too low for significant sorption of copper or zinc to occur at these locations. The simulated and measured values indicated copper sorption of as much as 30 percent in the epilimnion at sites $\mathrm{T} 2 \mathrm{~B}$ and $\mathrm{T} 1 \mathrm{~A}$, and the model predicted minimal zinc sorption in the epilimnion at sites T2B and T1A. In summary, concentrations of suspended particulate material and $\mathrm{pH}$ values were too small for substantial sorption of copper or zinc to the particulate phase to occur in Terrace Reservoir. Field data and model simulations indicate that some sorption of copper probably occurred when reservoir $\mathrm{pH}$ values were greater than about 6.

During July and August 1994, vertical variations in metal concentrations were large due to stratification, routing of inflow to the hypolimnion, and limited mixing between layers. Longitudinal variations in metal concentrations were small (fig. 10) due to residence times and horizontal mixing within limnetic layers. The metals primarily were dissolved, and concentrations throughout the reservoir in July and August (figs. 10 and 11) generally were larger than during June (fig. 9). The dominance of the dissolved fraction indicated that there was little particulate metal. Metal concentrations in the inflow during this period also were predominantly in the dissolved fraction, with the exception of aluminum and iron (Ferguson and Edelmann, 1996). Iron and aluminum primarily were transported in the suspended fraction, and the dominance of the dissolved fraction throughout the water column during this period indicates that sedimentation in Terrace Reservoir removed a substantial portion of the iron and aluminum concentrations.

Dissolved-metal concentrations were substantially larger in the epilimnion during July (fig. 10) than during June (fig. 9); generally, dissolved-metal concentrations were similar or slightly greater in the epilimnion during August than during July (figs. 10 and 11). The elevated epilimnetic metal concentrations in July and August probably reflect concentrations of metals in the inflow that entered the epilimnion as overflow and mixed with older water. The small variations in longitudinal metal concentrations between sites T5 and T2B/T1A probably were more the result of mixing of water with different metal concentrations than a result of precipitation, co-precipitation, or adsorption.

At sites T2B and T1 A in July and August, the dissolved-metal concentrations were larger in the hypolimnion than in the epilimnion, which was probably due to sampling of water with different residence times as a result of the dominance of underflow. The dominance of underflow resulted in discharge of water with low $\mathrm{pH}$ and the largest metal concentrations from the reservoir near site AR31.0. 


\section{Metal Chemistry During a Well-Mixed, Low-pH Period}

During September 1994, metal concentrations were substantially larger at sites T2B and T1A than at site T5 (fig. 12). Residence times were long, extending the time during which chemical and physical processes could affect metal chemistry; and the reservoir was well oxygenated, well mixed, and metal concentrations varied little with depth (figs. $3 B, 4 B, 5$, and 12). The reservoir pool had receded to the point that $\mathrm{T} 5$ was part of the Alamosa River and the $\mathrm{pH}$ of the inflow at site T5 was 6.0, whereas the $\mathrm{pH}$ at sites $\mathrm{T} 2 \mathrm{~B}$ and $\mathrm{T} 1 \mathrm{~A}$ was uniformly about 5.0 (fig. $7 B$ ).

At site $\mathrm{T} 5$, iron and aluminum largely were in the particulate fraction, whereas copper, cadmium, manganese, and zinc largely were in the dissolved fraction. All metals at sites T2B and T1A were predominantly in the dissolved fraction. The increase in dissolved-metal concentrations between sites $\mathrm{T} 5$ and $\mathrm{T} 2 \mathrm{~B} / \mathrm{T} 1 \mathrm{~A}$ probably was due largely to sampling of water that had entered the reservoir at different times and that had different metal concentrations. Metal concentrations measured at site T5 were less in September than in August (figs. 11 and 12). Metal concentrations at sites $T 2 B$ and $T 1 A$ in September were similar (generally within 10 percent) to the average metal concentrations in the reservoir in August, indicating that metal concentrations at sites T2B and T1A in September resulted largely from reservoir mixing that occurred about mid-September.

\section{Metal Chemistry During a Period of Ice Cover and Elevated Hypolimnetic pH}

During March 1995, the reservoir was completely covered by about $2 \mathrm{ft}$ of ice. The reservoir outlet was closed and only a small volume of water was discharged from the reservoir due to seepage through the dam or leakage around outlet works, or a combination of both. Although the reservoir was thermally mixed, slight density gradients in the reservoir were created by differences in dissolved-solids concentrations between the inflow and reservoir water (fig. 4). Specific-conductance data indicate that inflow had higher dissolved-solids concentrations than reservoir water, and this inflow was routed to the deeper depths of the reservoir. The ice cap impeded mixing of reservoir water by wind. Consequently, reservoir chemistry varied longitudinally and vertically.

As a result of inflow routing, the higher $\mathrm{pH}$ of the inflow resulted in an increase in $\mathrm{pH}$ with depth (fig. 7B). Dissolved-metal concentrations near the reservoir surface were smaller in the upstream end of the reservoir at site $\mathrm{T} 5$ than near the dam at site T1A, and dissolved-metal concentrations decreased markedly with depth (fig. 13). During March 1995, dissolved-metal concentrations generally were less than during September 1994 (figs. 12 and 13), probably as a result of smaller dissolved-metal concentrations that entered the reservoir. The longitudinal variations in metal concentrations probably were due largely to sampling of water that entered the reservoir at different times and to variable mixing.

The increase in $\mathrm{pH}$ and the large decrease in dissolved-metal concentrations that occurred with depth were a result of routing higher $\mathrm{pH}$, low-metal-concentration inflow to a deeper part of the reservoir. Dissolved-iron concentrations at sites T2B and T1A decreased with depth by 73 and 91 percent, respectively (fig. 13). Concurrent with the vertical decrease in dissolved-iron concentrations, the percent dissolved fraction of iron decreased with depth. Iron predominantly was dissolved near the reservoir surface. Near the reservoir bottom, iron and aluminum predominately were in the particulate fraction, reflecting the characteristics of the inflow. A considerable part of the aluminum near the reservoir bottom also was in the particulate fraction: about 75 percent at site $\mathrm{T} 5$; about 40 percent at site T2B; and about 30 percent at site T1A. Cadmium, copper, manganese, and zinc predominantly were in the dissolved fraction throughout the water column. Although not to the same extent, aluminum, cadmium, copper, manganese, and zinc concentrations also decreased with depth. Concentrations of dissolved aluminum decreased with depth by 50 to 60 percent; dissolvedcopper concentrations decreased with depth by 44 to 55 percent; and cadmium, manganese, and zinc concentrations generally decreased with depth by 20 to 30 percent. The decrease in metal concentrations with depth was due to underflow, and concentrations in the hypolimnion reflected the metal concentrations of the inflow. 

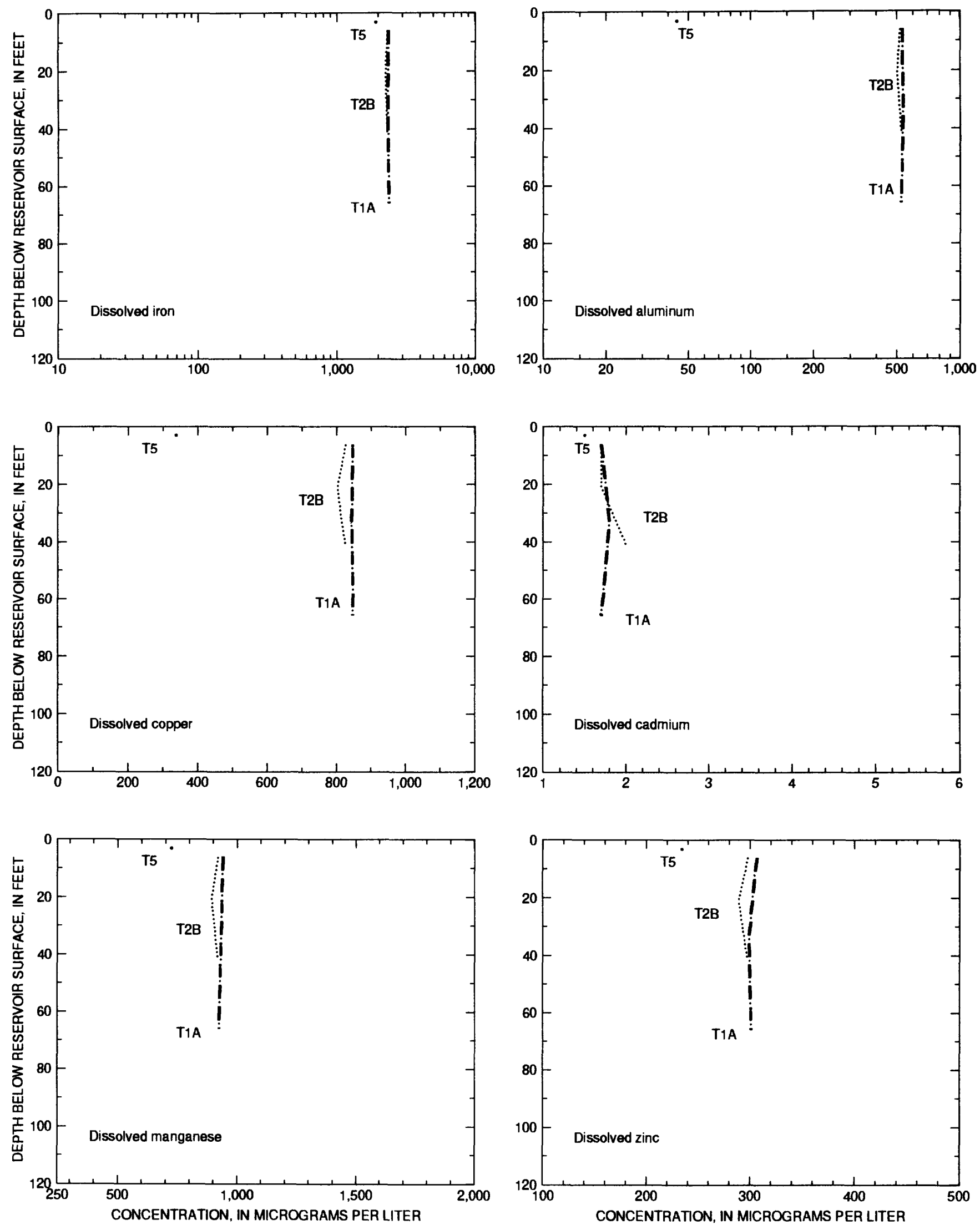

Figure 12. Dissolved-metal concentrations in Terrace Reservoir, September 1994. 

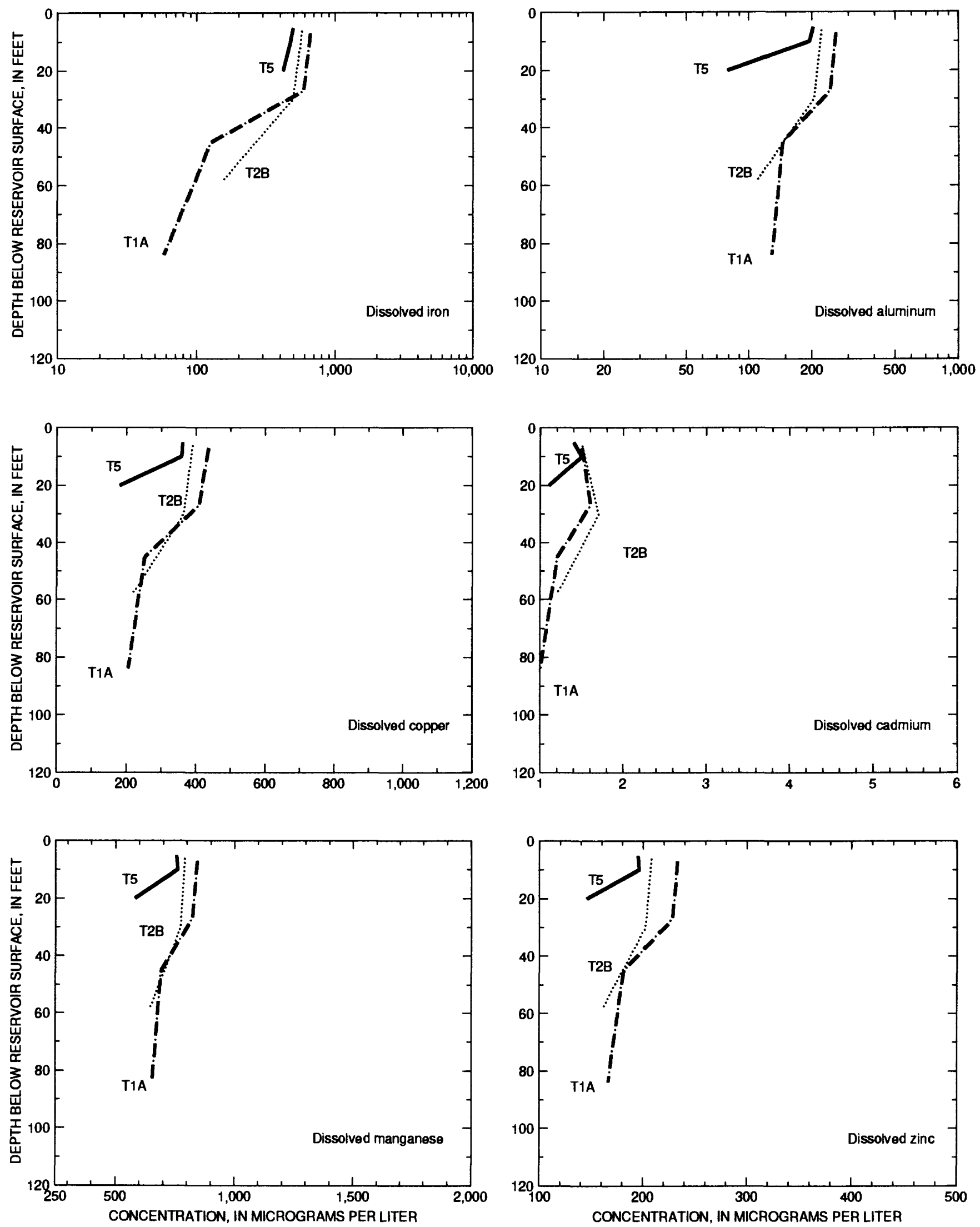

Figure 13. Dissolved-metal concentrations in Terrace Reservoir, March 1995. 


\section{SUMMARY}

Terrace Reservoir is a small bottom-draining irrigation reservoir located on the Alamosa River in the San Juan Mountain Range in Conejos County, Colorado. Reservoir storage fluctuates in response to variations in inflow, outflow, and demand for irrigation water in the southwestern part of the San Luis Valley. Between November and about mid-April, reservoir outlet works are closed, and storage gradually increases. During May and June 1994, the reservoir was at its annual maximum volume of about 12,000 acre-ft. Between July and mid-August, the reservoir volume decreased about 55 percent to about 5,400 acre- $\mathrm{ft}$ due to irrigation demand. Terrace Reservoir receives drainage of low$\mathrm{pH}$, metal-enriched water from mineralized areas, including the Summitville Mine, within the Alamosa River Basin. Drainage from the Summitville Mine contributes a substantial part of the metal load to Terrace Reservoir. Limited historical water-quality information is available for Terrace Reservoir. However, in 1974, water quality did not exceed water-quality standards.

Stratification patterns in Terrace Reservoir varied temporally. Thermal stratification of Terrace Reservoir developed about mid-May 1994. The reservoir remained stratified through August. Thermal stratification was absent from September 1994, following fall turnover, through March 1995, until ice-off conditions permitted surface warming and the reestablishment of thermal stratification in May 1995. Temperature varied little between two sites along transects in the reservoir (sites T2A and T2B; sites T1A and T1B). In June, specific conductance was variable with depth; in July and August, specific conductance increased with depth; from September through November, specific conductance was uniform with depth; from January through March, specific conductance increased with depth; and in May, specific conductance was again uniform with depth.

Initial inflow-routing and flow-through patterns were dictated by periodic density gradients and stratification that developed as a result of differences in water temperature and dissolved-solids concentration between the inflow and reservoir water. Underflow was the dominant flow path into and through Terrace Reservoir during periods of stratification. During periods of thermal stratification, residence times of inflowing water were strongly affected by flow routing. The reservoir discharges hypolimnetic water due to the location of the reservoir outlet on the bottom near the dam. With diminished vertical mixing, a dominance of underflow, and the location of the reservoir outlet, the residence times of water entering the epilimnion are greater than the residence times of water entering the metalimnion or hypolimnion during periods of stratification. During periods of stratification, residence times of inflowing water were shortened by 40 to 75 percent of the theoretical residence times for a well-mixed reservoir. Estimated residence times of water entering Terrace Reservoir were about 3 to 5 days during peak snowmelt runoff when the reservoir was thermally stratified. The short residence time reduced the amount of time during which physical and chemical processes could occur that might decrease metal concentrations before the water is released from the reservoir.

Concentrations of suspended solids entering Terrace Reservoir (site AR34.5) varied from 26 to $658 \mathrm{mg} / \mathrm{L}$ during spring snowmelt and summer storms of 1994 to the analytical detection level of $4 \mathrm{mg} / \mathrm{L}$, or less, during the winter of 1995 . Transport and deposition of suspended solids in Terrace Reservoir varied spatially and temporally in response to changes in flow characteristics. Under all conditions, most of the suspended solids were deposited in Terrace Reservoir.

During the study period, the concentration of dissolved oxygen varied longitudinally, vertically, and temporally in response to changes in water temperature. The Alamosa River provided a consistent supply of well-oxygenated water to the reservoir. Dissolved-oxygen concentrations in the reservoir generally were within $0.5 \mathrm{mg} / \mathrm{L}$ of the dissolved-oxygen concentration of the inflow. The $\mathrm{pH}$ of water in the reservoir generally ranged from about 4.0 to about 7.0, depending on sample date, depth, and location. The largest $\mathrm{pH}$ values were measured during May 1994 and 1995 prior to peak snowmelt runoff. Generally, $\mathrm{pH}$ decreased with depth and downstream direction. Fall turnover in September generally mixed the reservoir waters, and $\mathrm{pH}$ generally was uniform with depth; however, $\mathrm{pH}$ values continued to be higher in the upstream reach of the reservoir. During February and March 1995, pH of reservoir water increased with depth. 
Dissolved- and total-recoverable-metal concentrations varied spatially and temporally in response to inflow characteristics and physical processes in Terrace Reservoir. The dissolved-metal fraction was the dominant phase in the reservoir. During June, the reservoir was thermally stratified, and large longitudinal and vertical variations occurred in metal concentrations. In the epilimnion, the elevated $\mathrm{pH}$ and decrease in metal concentrations from the upstream end of the reservoir to the dam was indicative of differences in chemistry of water that had entered the reservoir at different times and settling of colloidal iron hydroxides. As a result of underflow and short residence times, dissolved-metal concentrations within the hypolimnion had considerably less longitudinal variation than occurred in the epilimnion. Limited geochemical modeling indicated that concentrations of suspended particulate matter and $\mathrm{pH}$ were too small for substantial sorption of copper and zinc to the particulate phase to occur in Terrace Reservoir.

During July and August, the dissolved-metal concentrations throughout the water column generally were larger than during June, and the metals were predominantly in the dissolved fraction. The elevated epilimnetic metal concentrations that occurred in the reservoir during July and August probably were the result of mixing of inflow, which had elevated metal concentrations, that entered the epilimnion as overflow. In addition, the small variations in longitudinal metal concentrations that occurred during July and August probably were more the result of mixing of water with different metal concentrations than the result of precipitation, co-precipitation, or adsorption. Within the hypolimnion, dissolved-metal concentrations were larger during July and August than during June, and the dissolved-metal concentrations in the hypolimnion were larger than the metal concentrations in the epilimnion, so the water with the largest concentrations was discharged from the reservoir.

During September, metal concentrations were substantially larger at site T1A than at site T5, and little vertical variations in metal concentrations occurred in the downstream part of the reservoir. In the upstream part of the reservoir, iron and aluminum were largely in the particulate fraction, and copper, cadmium, manganese, and zinc were largely in the dissolved fraction. In the downstream part of the reservoir, all metals were predominantly in the dissolved fraction. During September, mixing strongly affected metal concentrations, as metal concentrations measured during September equaled average metal concentrations measured during August.

During March, the reservoir was thermally well mixed; slight density gradients in the reservoir were created by differences in dissolved-solids concentrations between the inflow and reservoir water; and reservoir chemistry varied longitudinally and vertically. The dissolved-metal concentrations in the reservoir during March generally were less than the concentrations measured in the reservoir during September. The largest metal concentrations occurred in the epilimnion. Large decreases in metal concentration occurred with depth as a result of underflow.

Factors or processes affecting distribution of metal concentrations in Terrace Reservoir are:

(1) Streamflow, water temperature, dissolved-oxygen concentration, $\mathrm{pH}$, specific conductance, and concentrations of metals in the Alamosa River upstream from Terrace Reservoir; and (2) physical factors and processes in Terrace Reservoir, which include stratification and mixing, inflow-routing and flow-through patterns, residence times, and sedimentation. The importance of these factors and processes in affecting distribution of metal concentrations in the reservoir varied with time. During periods of stratification, mixing within layers and initial flow-routing and flowthrough patterns affected the distribution of inflow and metal concentrations in the reservoir. Variations in metal concentrations in inflowing water and the dominance of underflow altered the distribution of metals in the reservoir. In the fall, when the reservoir was well mixed, metal concentrations were uniform. In the winter, when the reservoir was covered with ice, differences in concentrations of dissolved solids between inflow and reservoir water created density gradients, which, in turn, affected flow routing and distribution of metal concentrations. Most of the suspended particulate matter and colloidal metal hydroxides settled from the water column in the upper part of the reservoir. 


\section{SELECTED REFERENCES}

Allison, J.D., Brown, D.S., and Novo-Gradac, K.J., 1991, MINTEQA2/PRODEFA2-A geochemical assessment model for environmental systems, version 3.0, user's manual: U.S. Environmental Protection Agency Report EPA/600/3-91/021, 106 p.

Anderson, R.F., and Schiff, S.L., 1987, Alkalinity generation and the fate of sulfur in lake sediments: Canadian Journal of Fisheries and Aquatic Sciences, v. 44, Supplement 1,p. 188-193.

Balistrieri, L.S., Ortiz, R.F., Briggs, P.H., Elrick, K.A., and Edelmann, P.F., 1996, Metal fluxes across the sediment-water interface in Terrace Reservoir, Colorado: U.S. Geological Survey Water-Resources Investigations Report 96-040, $83 \mathrm{p}$.

Boyles, J.M., Cain, D.J., Alley, W., and Klusman, R.W., 1974, Impact of Argo Tunnel acid mine drainage, Clear Creek County, Colorado, in Proceedings - Water resources problems related to mining: American Water Resources Association Proceedings 18, p. 41-53.

Britton, L.J., and Gaggiani, N.G., 1987, Water-quality assessment of Arvada Reservoir, Denver metropolitan area, Colorado: U.S. Geological Survey WaterResources Investigations Report 87-4107, 66 p.

Britton, L.J., and Wentz, D.A., 1980, Water-quality characteristics of selected lakes and reservoirs in Colorado:

U.S. Geological Survey Open-File Report 80-436, $139 \mathrm{p}$.

Cain, Doug, 1995, Factors affecting surface-water quality in the Alamosa River Basin, south-central Colorado, in Posey, H.H., Pendelton, J.A., and Van Zyl, D.J.A., eds., Proceedings - Summitville Forum '95: Denver, Colorado Geological Survey Special Publication 38, p. 159.

Dzombak, D.A., and Morel, F.M.M., 1987, Adsorption of inorganic pollutants in aquatic systems: Journal of Hydraulic Engineering, v. 113, p. 430-475.

Edwards, T.K., and Glysson, G.D., 1988, Field methods for measurement of fluvial sediments: U.S. Geological Survey Open-File Report 86-531, 118 p.

Ferguson, Sheryl, and Edelmann, Patrick, 1996, Assessment of metal transport into and out of Terrace Reservoir, Conejos County, Colorado, April 1994 through March 1995: U.S. Geological Survey WaterResources Investigations Report 96-4151.

Goldman, C.R., and Horne, A.J., 1983, Limnology: New York, McGraw-Hill, 464 p.

Hamilton, J.L., 1989, Investigation of water supply for a private residence southwest of Monte Vista, Rio Grande County, Colorado, in Water in the valley, a 1989 perspective on water supplies, issues, and solutions in the San Luis Valley, Colorado: Colorado Ground Water Association, eighth annual field trip, August 19-20, 1989, p. 262-267.

Horowitz, A.J., 1991, A primer on sediment-trace element chemistry: Chelsea, Mich., Lewis Publishers, Inc., $136 \mathrm{p}$.

Horowitz, A.J., Lum, K.R., Garbarino, J.R., Hall, G.E.M., Lemieux, C., and Demas, C.R., 1996, Problems associated with using filtration to define dissolved trace element concentrations in natural waters: Environmental Science and Technology, v. 30, p. 954-963.

Kimball, B.A., Callender, E., and Axtmann, E.V., 1995, Effects of colloids on metal transport in a river receiving acid mine drainage, upper Arkansas River, Colorado, U.S.A.: Applied Geochemistry, v. 10, p. 285-306.

King, T.V.V., ed., 1995, Environmental considerations of active and abandoned mine lands: U.S. Geological Survey Bulletin 2220, 38 p.

Lewis, M.E., and Edelmann, Patrick, 1994, Physical, chemical, and biological characteristics of Pueblo Reservoir, Colorado, 1985-89: U.S. Geological Survey Water-Resources Investigations Report 94-4097, 71 p.

Miller, W.M., and McHugh, J.B., 1994, Natural acid drainage from altered areas within and adjacent to the upper Alamosa River Basin, Colorado: U.S. Geological Survey Open-File Report 94-144, 47 p.

Moran, R.E., and Wentz, D.A., 1974, Effects of metalmine drainage on water quality in selected areas of Colorado, 1972-73: Denver, Colorado Water Resources Circular 25, $250 \mathrm{p}$.

Morrison and Knudsen Corporation, and ICF Keiser Engineers, 1994, Summitville Mine site-Ecological risk assessment work plan.

Mueller, D.K., and Ruddy, B.C., 1992, Limnological characteristics, nutrient loading and limitation, and potential sources of taste and odor problems in Standley Lake, Colorado: U.S. Geological Survey Water-Resources Investigations Report 92-4053, 55 p.

Mueller, Mary, and Mueller, T.A., 1995, Surface water quality of the Alamosa River and selected tributaries, 1972 to 1994, in Posey, H.H., Pendelton, J.A., and Van Zyl, D.J.A., eds., Proceedings — Summitville Forum '95: Denver, Colorado Geological Survey Special Publication 38, p. 192-214.

Ortiz, R.F., von Guerard, P.B., and Walton-Day, Katherine, 1995, Effect of a localized rainstorm on the water quality of the Alamosa River upstream from Terrace Reservoir, south-central Colorado, August 9-10, 1993, in Posey, H.H., Pendelton, J.A., and Van Zyl, D.J.A., eds., Proceedings - Summitville Forum '95: Denver, Colorado Geological Survey Special Publication 38, p. $178-182$. 
Posey, H.H., Pendelton, J.A., and Van Zyl, D.J.A., eds., 1995, Proceedings - Summitville Forum '95: Denver, Colorado Geological Survey Special Publication 38, $375 \mathrm{p}$.

Smith, K.S., 1991, Factors influencing metal sorption onto iron-rich sediment in acid-mine drainage: Golden, Colorado School of Mines, Ph.D. dissertation T-3925, $239 \mathrm{p}$.

Smith, K.S., Ficklin, W.H., Plumlee, G.S., and Meier, A.L., 1992, Metal and arsenic partitioning between water and suspended sediment at mine-drainage sites in diverse geologic settings, in Kharaka, Y.K., and Maest, A.S., eds., Water-rock interaction-Proceedings of the 7th International Symposium on WaterRock Interaction, Park City, Utah, July 13-18, 1992: Rotterdam, A.A. Balkema, WRI-7, p. 443-447.

Sylvester, M.A., Kister, L.R., and Garrett, W.B., eds., 1990, Guidelines for the collection, treatment, and analysis of water samples -U.S. Geological Survey western region field manual: Unpublished report on file in the Pueblo, Colo., Water Resources Division Office of the U.S. Geological Survey, 144 p.

Thornton, K.W., Kimmel, B.L., and Payne, F.E., eds., 1990, Reservoir limnology-Ecological perspectives: New York, John Wiley, 246 p.

U.S. Environmental Protection Agency, 1993, Summitville mine removal action, site summary: Denver.

Walton-Day, Katherine, Ortiz, R.F., and von Guerard, P.B., 1995, Sources of water having low $\mathrm{pH}$ and elevated metal concentrations in the upper Alamosa River from the headwaters to the outlet of Terrace Reservoir, south-central Colorado, April-September, 1993, in
Posey, H.H., Pendleton, J.A., and Van Zyl, D.J.A., eds., Proceedings—Summitville Forum '95: Denver, Colorado Geological Survey Special Publication 38, p. $160-170$.

Ward, J.R., and Harr, C.A., eds., 1990, Methods for collection and processing of surface-water and bedmaterial samples for physical and chemical analyses: U.S. Geological Survey Open-File Report 90-140, $71 \mathrm{p}$.

Ward, E.C., and Walton-Day, Katherine, 1995, Seasonal variations in water quality on Wightman Fork of the Alamosa River, 1993, in Posey, H.H., Pendelton, J.A., and Van Zyl, D.J.A., eds., Proceedings—Summitville Forum '95: Denver, Colorado Geological Survey Special Publication 38, p. 183-190.

Watts, K.R., 1996, Bathymetric surface and storage capacity of Terrace Reservoir, Conejos County, Colorado, July-August 1994: U.S. Geological Survey Water-Resources Investigations Report 96-4027, scale $1: 4,800$.

Wetzel, R.G., 1983, Limnology: Philadelphia, W.B. Saunders, $767 \mathrm{p}$.

Woodling, J.D., 1995, Historic fisheries records-Alamosa River, in Posey, H.H., Pendelton, J.A., and Van Zyl, D.J.A., eds., Proceedings—Summitville Forum '95: Denver, Colorado Geological Survey Special Publication 38, p. 228-235.

Wunderlich, W.O., 1971, The dynamics of density-stratified reservoirs, in Reservoir fisheries and limnology: American Fisheries Society Special Publication 8, p. 219-230. 